
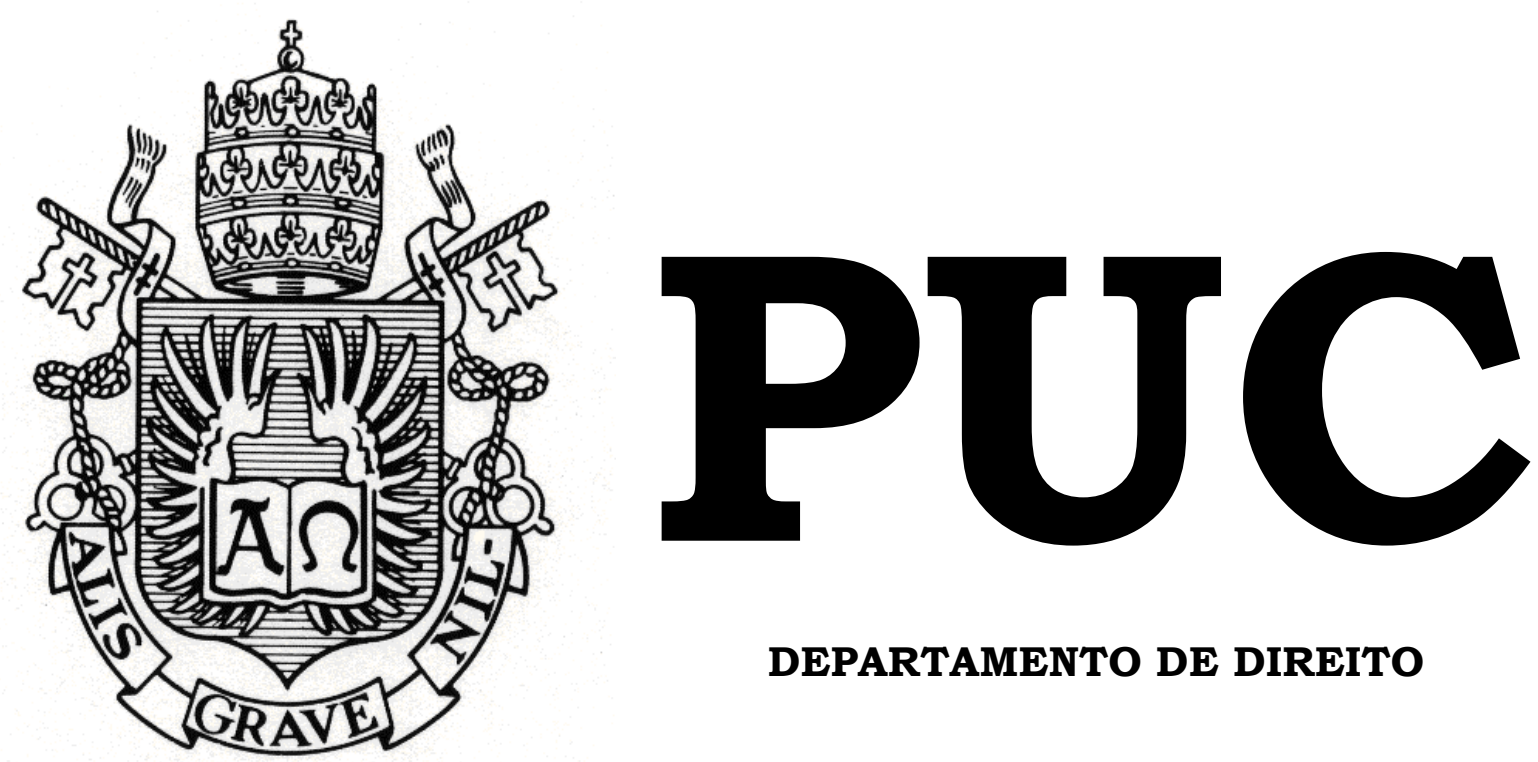

DEPARTAMENTO DE DIREITO

A Teoria da Cegueira Deliberada e sua aplicação no delito de Lavagem de Capitais

por

Rodrigo da Rocha Gurgel do Amaral

ORIENTADOR: BRENO MELARAGNO COSTA 2018.1

PONTIFÍCIA UNIVERSIDADE CATÓLICA DO RIO DE JANEIRO

RUA MARQUÊS DE SÃO VICENTE, 225 - CEP 22453-900

RIO DE JANEIRO - BRASIL 


\title{
A Teoria da Cegueira Deliberada e sua aplicação no delito de Lavagem de Capitais
}

\author{
por \\ Rodrigo da Rocha Gurgel do Amaral
}

Monografia apresentada ao

Departamento de Direito da Pontifícia Universidade Católica do Rio de Janeiro (PUC-Rio) para a obtenção do Título de Bacharel em Direito.

Orientador: Breno Melaragno Costa 


\section{Resumo}

A teoria da cegueira deliberada ou willfull blindness é uma construção jurisprudencial do sistema de common law que institui a responsabilização penal subjetiva de indivíduos que, no intuito de se esquivar do conhecimento da natureza ilícita de seus atos, criam obstáculos e barreiras para impedir sua consciência acerca do delito.

A bem da verdade, traçando um paralelo com o ordenamento jurídico brasileiro, a cegueira deliberada seria uma espécie de dolo eventual avultado, onde o agente, com o fito de obter vantagens e facilitações indevidas e com a plena capacidade de identificar a proveniência dos recursos, pretexta desconhecê-la.

Nesse diapasão, o presente trabalho pretende demonstrar a origem, aplicação e aceitação da cegueira deliberada nos países de common law, para depois dispor sobre sua adaptação ao Direito Penal Brasileiro, com especial enfoque no instituto do dolo eventual nos delitos de branqueamento de capitais.

A partir destas anotações, objetiva-se desenvolver críticas ao uso indiscriminado da teoria em questão e apontar como a jurisprudência brasileira poderia aplica-la sem que, para tanto, extinga-se a necessidade da demonstração do nexo doloso entre o agente e a conduta tipificada.

Palavras-chave: Cegueira deliberada; Dolo Eventual; Responsabilidade Subjetiva, Lavagem de Capitais, Common Law; Elemento subjetivo. 


\section{SUMÁRIO}

I. INTRODUÇÃO .05

II. A TEORIA DA CEGUEIRA DELIBERADA NO SISTEMA DO COMMON LAW E SEU DESENVOLVIMENTO HISTÓRICO...........................08

II.I. Críticas À Aplicação Da Teoria Da Cegueira Deliberada Nos Estados Unidos Da América...................................................................14

III. O DELITO DE LAVAGEM DE CAPITAIS NO BRASIL..............21

III.I. O desenvolvimento histórico do crime e principais inovações legislativas.................................................................................21

III.II. Os elementos subjetivos do crime...........................................30

III.III. A impossibilidade do crime de lavagem de capitais na modalidade culposa.

.38

IV. A INTRODUÇÃO DA DOUTRINA DA CEGUEIRA DELIBERADA NO ORDENAMENTO JURÍDICO BRASILEIRO...............................42

IV.I. A cegueira deliberada na doutrina e jurisprudência brasileira. .42

IV.I.I. O furto ao Banco Central.....................................................46

IV.I.II. O julgamento da Ação Penal 470 ("Mensalão") ...................50

IV.I.III. As decisões da 13 ${ }^{\underline{a}}$ Vara Federal de Curitiba......................55

V. CONSIDERAÇÕES FINAIS. .61

VI. REFERÊNCIAS BIBLIOGRÁFICAS. .64 


\section{CAPÍTULO I. INTRODUÇÃO}

"The willful blindness doctrine, while providing courts with a useful tool for bringing culpable individuals to justice, also carries with it the dangerous potential to convict those whose mental state does not reach the requisite level of culpability." 2

Nos Estados Unidos, vem ganhando cada vez mais espaço na doutrina e na jurisprudência, em especial nos crimes ditos de colarinho branco, um novo tipo de elemento subjetivo, onde não precisa restar demonstrado o fim específico de delinquir, tampouco a consciência e aceitação do resultado delituoso, bastando que o indivíduo, tendo a suspeita do ilícito cometido e a possibilidade de aprofundar-se sobre seus contornos, nada faz e nada procura fazer.

Seria uma forma de tentar se esconder dos verdadeiros contornos do ato, enterrando-se na obscuridade, tal como faz um avestruz diante de um perigo iminente.

A teoria da cegueira deliberada ou das instruções do avestruz, nos moldes da doutrina inglesa e norte-americana, aduz serem criminalmente responsáveis os indivíduos que se colocam pensadamente em uma posição de desconhecimento e ignorância em relação a eventuais ilícitos praticados.

É uma situação onde tem-se a capacidade de saber, deve-se procurar saber, mas escolhe-se não saber para evitar constrangimentos e responsabilidades.

Uma vez definidos o conceito e interpretações da teoria da cegueira deliberada, abordar-se-á seu desenvolvimento histórico, mostrando sua origem, desdobramentos e aplicação no cenário fático internacional.

\footnotetext{
${ }^{1}$ Harvard Law Review. Criminal Law - Willful Blindness - Ninth Circuit Holds That Motive Is Not An Element Of Willful Blindness. - United States v. Heredia, 483 F.3d 913 (9th Cir.) (en banc), cert. denied, 76 U.S.L.W. 3303 (U.S. Dec. 11, 2007) (No.07-5762)

${ }^{2}$ Em tradução livre: A teoria da cegueira deliberada, enquanto proporciona aos tribunais uma ferramenta útil para condenar acusados culpados, também traz consigo o perigoso potencial de se condenar aqueles onde o estado subjetivo não representa o nível de culpabilidade requerido no tipo penal.
} 
Em um segundo momento, faz-se imprescindível tratar da introdução da doutrina da ignorância deliberada no ordenamento jurídico pátrio, demonstrando como ela pode ser aplicada pelos tribunais brasileiros, dandose especial atenção aos delitos de branqueamento de capitais.

Para tanto, trataremos da evolução e desenvolvimento do tipo penal em comento, discorrendo sobre sua origem, suas alterações de maior relevância e, principalmente, sobre seus elementos subjetivos.

O crime de lavagem de dinheiro está previsto na Lei $n^{\circ}$ 9.613/98, mais precisamente no caput do artigo $1^{\circ}$, cuja redação é a que segue: "Art. $1^{\circ}$ Ocultar ou dissimular a natureza, origem, localização, disposição, movimentação ou propriedade de bens, direitos ou valores provenientes, direta ou indiretamente, de infração penal".

A legislação, a jurisprudência e a doutrina majoritária são uníssonas ao afirmar que o crime de lavagem de dinheiro apenas abarca uma modalidade subjetiva: o dolo.

Mas podemos perceber, a partir do estudo de casos concretos, que há uma tendência em se relativizar a constatação do dolo, situações onde nos encontramos diante de uma imprudência culposa, mas que acaba por ser definida pelo julgador como dolosa. Em um direito penal regido pelo finalismo, tal qual o brasileiro, esta interpretação pode vir a ser extremamente preocupante, caso não seja precedida de minuciosa análise e deliberação.

É nesse âmbito que a teoria da ignorância deliberada se encaixa, neste liame tênue entre o dolo eventual e a culpa. Isto posto, o presente estudo se debruçará sobre os conceitos de dolo eventual, dolo direto e culpa consciente, consagrados na linha da mais balizada doutrina, relacionando-os diretamente com o crime de lavagem de dinheiro. Afigura-se fundamental evitar uma objetivação da conduta dolosa, normatizando-se os conceitos de conhecimento e vontade do agente, sob pena de transitar pelo campo da 
odiosa responsabilidade penal objetiva, há muito extirpada do ordenamento jurídico pátrio. ${ }^{3}$

Por fim e oportuno, a dissertação aqui apresentada exibirá críticas e considerações à aplicação da teoria da cegueira deliberada no delito de lavagem de capitais, demonstrando como pode vir a ser maléfica sua utilização indiscriminada, mas também apontando sua utilidade e valia em certos casos.

\footnotetext{
${ }^{3}$ Borges de Albuquerque Mello, Sebastian e Ribeiro Hernandes, Camila. O Delito De Lavagem De Capitais E A Teoria Da Cegueira Deliberada: Compatibilidade No Direito Penal Brasileiro? CONPEDI Law Review. 2017. Página 442.
} 


\section{CAPÍTULO II. A TEORIA DA CEGUEIRA DELIBERADA NO SISTEMA DO COMMON LAW E SEU DESENVOLVIMENTO HISTÓRICO}

Como já abordado na introdução da presente dissertação, a teoria da cegueira deliberada teve início nos países de common law, em especial na Inglaterra e nos Estados Unidos.

Um dos primeiros registros do uso da referida doutrina como embasamento para um órgão julgador data de 1860, no caso Regina v. Sleep, onde o excelentíssimo magistrado Judge Willes, em seu veredito final absolutório, aduziu que o júri não restou convencido de que o acusado tinha a intenção no cometimento do ilícito pelo qual fora acusado ou de que ao menos teria usado de artifícios para deliberadamente evitar o conhecimento do ilícito. ${ }^{4}$

Vale dizer que, caso houvesse o elemento objetivo constatando que o acusado evitou o conhecimento do ilícito propositalmente, o mesmo se encontraria condenado. ${ }^{5}$

Para melhor ilustrar o entendimento evidenciado no decisum, vale expor, ainda que sucintamente, a situação fática do caso.

Narra-se que o acusado fora encontrado em posse de bens e materiais próprios de embarcações marítimas, sendo certo que alguns desses bens estavam rotulados com o símbolo oficial do Governo. A ofensa pela qual o defendido fora denunciado demandava o efetivo conhecimento de que os bens eram de propriedade da Coroa Inglesa. A defesa arguiu a ignorância do negociante de ferragens e, como já dito, o mesmo restou absolvido pelos fundamentos acima expostos.

\footnotetext{
4 Ira P. Robbins, The Ostrich Instruction: Deliberate Ignorance as a Criminal Mens Rea, 81 J. Crim. L. \& Criminology 191 (1990-1991). P 196 e 197.

5 Ira P. Robbins, The Ostrich Instruction: Deliberate Ignorance as a Criminal Mens Rea, 81

J. Crim. L. \& Criminology 191 (1990-1991). P 197.
} 
O caso acima citado tornou-se um leading case no ordenamento jurídico britânico, que passou a utilizar a doutrina da cegueira deliberada cada vez com mais frequência, passando, inclusive, a se tornar uma alternativa viável para se condenar aqueles onde não se podia ou conseguia provar a real intenção e ciência delitiva.

Em muitos julgados subsequentes não se considerou imprescindível o fim específico de agir ou a assunção do risco e aceitação do resultado, bastava a suspeita e a possibilidade da ocorrência do ato, aliada à inércia dos acusados em obter as informações necessárias para o esclarecimento do fato.

Quando era possível provar que o acusado havia se abstido proposital e intencionalmente de angariar dados e informações sobre a ilicitude do ato, o mesmo seria igualmente culpável àquele onde foi efetivamente comprovada a ciência do ilícito. ${ }^{6}$

Nesse sentido, diversas discussões emergiram para determinar qual seria a conduta necessária para restar comprovado que o acusado estava deliberadamente se colocando em uma posição de ignorância.

Alguns afirmavam ser necessária uma mera imprudência do defendido, pois em uma situação onde o ilícito era absolutamente óbvio, ele nada teria feito para evitar seu cometimento. Outros, acreditavam ser necessário o simples fato do acusado não investigar um ato potencial $\mathrm{e}$ possivelmente contrário à lei.

Apesar de controversa, esta ilação fora amplamente utilizada pelas cortes inglesas no final do século XIX e não demorou muito até conquistar seu espaço na doutrina e jurisprudência norte-americana.

Como forma de introduzir a ignorância deliberada nos Estados Unidos, pode-se citar o emblemático caso Spurr v. United States, datado de

\footnotetext{
${ }^{6}$ Daniel, Alex Robert, "Willful Blindness: The Hazards of an Evolving Standard of Knowledge" (2013). Law School Student Scholarship. Paper 347. P. 5
} 
1899, onde a Suprema Corte Americana abordou, pela primeiríssima vez, a teoria da cegueira deliberada em seu decisum final. ${ }^{7}$

Em suma, o caso diz respeito ao Presidente do Commercial Bank of Nashville, acusado de autenticar uma série de cheques de um cliente do banco que não possuía fundos em sua conta corrente. A corte suprema interpretou a cegueira deliberada como o conhecimento do ato e intenção perversa de cometê-lo, aduzindo, ainda, que a citada intenção perversa poderá ser presumida caso provado que o acusado tenha fechado seus olhos, relegandose para a ignorância quanto à suficiência dos fundos da conta.

A corte ainda afirmou que o acusado poderia ser condenado caso tivesse se recusado a empreender investigações e questionamentos no intuito de evitar o conhecimento do ilícito. Não obstante, o Sr. Spurr foi absolvido dos crimes a ele imputados, devido à ausência de uma resposta adequada do juiz da instrução ao júri quando indagado sobre o conceito de "autenticação deliberada" no processo em primeira instância. ${ }^{8}$

Apesar da absolvição, foi a primeira vez que a Suprema Corte Americana se debruçou sobre a teoria em questão, aduzindo ser possível uma condenação criminal em razão de uma cegueira ou ignorância deliberadamente criada.

Seguindo a repercussão ocasionada por conta do caso Spurr v. United States, a cegueira deliberada foi utilizada em diversos procedimentos falimentares federais americanos, mas foi só em 1970, quase um século depois, que a teoria teve seu momento de maior relevância no ordenamento jurídico estadunidense.

O contexto histórico dos anos 70 nos Estados Unidos foi marcado por um uso alarmante de entorpecentes e uma grande parcela da população, em

\footnotetext{
${ }^{7}$ RAGUÉS I VALLÈS, Ramon. La ignorancia deliberada em derecho penal. Barcelona: Atelier, 2007. p. 67

${ }^{8}$ Ira P. Robbins, The Ostrich Instruction: Deliberate Ignorance as a Criminal Mens Rea, 81

J. Crim. L. \& Criminology 191 (1990-1991). P. 198
} 
especial a parcela marginalizada e com menor poder aquisitivo, com problemas de vício e dependência de drogas.

Nesse sentido, a política repressiva estatal se baseou na lei do Controle e Prevenção Geral do abuso de Drogas de $1970^{9}$, na qual eram considerados culpados aqueles que, conscientemente, participavam do processo de importação e exportação das substâncias listadas na lei, ou que as possuíam com intenção de distribuir ou comercializar.

A palavra-chave que aqui se destaca é o conscientemente. Partindo desta premissa na legislação, as defesas dos supostos traficantes baseavamse, em sua ampla maioria, na ignorância sobre a operação criminosa.

Percebendo a situação, o Estado e a Procuradoria vislumbraram a necessidade e o benefício de se equiparar a ignorância deliberada ao pleno conhecimento do fato, o que reduziria o ônus probatório da acusação, vez que é muito mais simples e menos custoso provar que certo indivíduo se colocou em uma situação de ignorância do que comprovar o efetivo conhecimento de um ato criminoso. ${ }^{10}$

Talvez um dos casos mais relevantes envolvendo a teoria da cegueira deliberada, inclusive servindo como a principal fonte de discussões sobre a doutrina nos dias atuais, seja o processo Jewell v. United States.

Trata-se de um procedimento criminal envolvendo a importação e transporte de narcóticos proibidos pela legislação, onde o defendido Jewell fora denunciado por ter transportado, conscientemente, em um compartimento secreto do seu veículo, a quantidade de 49 quilogramas de maconha para distribuição.

Havia evidências circunstanciais atestando que o defendido teria conhecimento da presença das substâncias ilícitas no interior do seu automóvel, contudo, também existiam elementos dando conta de que o acusado não sabia ao certo o que transportava consigo, vez que

\footnotetext{
${ }^{9}$ Comprehensive Drug Abuse Prevention and Control Act of 1970

${ }^{10}$ Ira P. Robbins, The Ostrich Instruction: Deliberate Ignorance as a Criminal Mens Rea, 81

J. Crim. L. \& Criminology 191 (1990-1991). P. 200
} 
deliberadamente evitou aperfeiçoar seu conhecimento para se esquivar de uma possível condenação por tráfico de entorpecentes. ${ }^{11}$

A defesa de Jewell pleiteou que fosse esclarecido ao júri que apenas poderia haver a condenação pelo delito em questão, caso o real conhecimento do fato fosse comprovado. Tal pleito restou indeferido pelo Juízo de instrução, ao argumento de que o acusado teria proposital e lucidamente evitado o conhecimento da verdade.

Nesta esteira, os jurados consideraram o defendido culpado, não restando a ele outra alternativa que não apelar do veredito condenatório.

O tribunal de apelação reiterou a condenação de Jewell expondo em três itens os motivos pelo qual foi considerada a equiparação da ignorância deliberada ao conhecimento de fato do delito.

O órgão colegiado entendeu por bem aduzir que a doutrina da cegueira deliberada já se encontrava consolidada no ordenamento jurídico estadunidense, inclusive evidenciando que o conhecimento de fato e a ignorância deliberada se manifestam como igualmente culpáveis no ilícito penal. A corte ainda satisfez o interesse da procuradoria ao afirmar que se assim não fosse, as defesas dos supostos traficantes de entorpecentes empregariam, sistematicamente, a ignorância para se eximir de quaisquer responsabilizações. ${ }^{12}$

$\mathrm{O}$ douto Tribunal ad quem assentou sua decisão nos ditames compreendidos no Model Penal Code ("MPC"), publicado em 1962 após longos 10 (dez) anos de elaboração, que seria uma espécie de consolidação criada pelo American Law Institute ("ALI") para orientar os estados americanos na atualização e uniformização da legislação criminal.

A definição de conhecimento manifestada no referido código, é no sentido de ser de fato o conhecimento quando presentes a alta probabilidade

\footnotetext{
${ }^{11}$ Ira P. Robbins, The Ostrich Instruction: Deliberate Ignorance as a Criminal Mens Rea, 81 J. Crim. L. \& Criminology 191 (1990-1991). P. 204

${ }^{12}$ Ira P. Robbins, The Ostrich Instruction: Deliberate Ignorance as a Criminal Mens Rea, 81

J. Crim. L. \& Criminology 191 (1990-1991). P. 205
} 
de existência do evento, salvo se o agente efetivamente acreditar que o fato não se concretizará.

Conceito similar ao de culpa consciente que apesar de não previsto no Código Penal Brasileiro (Decreto-Lei No 2.848, de 7 de dezembro de 1940), é uma construção doutrinária de ampla aceitação, conforme preleciona o ilustre Professor e Desembargador Guilherme de Souza Nucci, verbis:

“(culpa consciente) é a chamada culpa com previsão, ocorrendo quando o agente prevê que sua conduta pode levar a um certo resultado lesivo, embora acredite, firmemente, que tal evento não se realizará, confiando na sua atuação (vontade) para impedir o resultado. "13

No entanto, a interpretação do conceito de conhecimento tal como disposto no Model Penal Code ("MPC") atribuída pela United States Court of Appeals for the Ninth Circuit (equiparado à um Tribunal Regional Federal) quando do julgamento do caso em cheque, no intuito de justificar sua condenação, está eivada de flagrantes vícios.

É que o Model Penal Code ("MPC") quando trata do elemento subjetivo da culpabilidade, o mens rea ${ }^{14}$, ou mente culpada em tradução livre, não prevê especificamente o instituto da teoria da cegueira deliberada. E é dessa lacuna legislativa que decorrem as mais relevantes e notáveis críticas à aplicação da doutrina.

Nesse cenário, é bem verdade que não seria justo e democrático considerar certa conduta como dolosa quando o próprio conceito de dolo presente na legislação não prevê sequer uma alínea sobre a hipótese de um evitamento deliberado do dolo. ${ }^{15}$

Isto posto, apontaremos no próximo tópico as principais correntes contrárias à aplicação indiscriminada da teoria da cegueira deliberada nos Estados Unidos, abordando e expondo quais pontos alcançam maior

\footnotetext{
${ }^{13}$ NUCCI, Guilherme de Souza. Código Penal Comentado / Guilherme de Souza Nucci. - 18 ed. rev., atual. e ampl. - Rio de Janeiro, Editora Forense. 2017. Página 219 e 220.

14 Mens rea seria a intenção que precede o ato criminoso. Tipicamente, deve-se haver uma vontade, um elemento subjetivo para que se possa configurar o crime. Disponível em: https://study.com/academy/lesson/mens-rea-vs-actus-reus-difference-comparison.html 15 ADORNO BANDEIRA ASSUMPÇÃO, Pedro Antonio. A Teoria da Cegueira Deliberada e
} a Equiparação ao Dolo Eventual. Rio de Janeiro. EMERJ, 2017. Página 8 e 9. 
relevância no ordenamento jurídico e, por fim, enumerando quais propostas são apresentadas pelos autores citados para consolidar e pacificar o instituto.

\section{II.I CRÍTICAS À APLICAÇÃO DA TEORIA DA CEGUEIRA DELIBERADA NOS ESTADOS UNIDOS DA AMÉRICA}

Como apontado no encerramento do capítulo que precede este, a teoria da cegueira deliberada, apesar de encontrar respaldo na mais alta corte dos Estados Unidos, devido à ausência de uma previsão legal específica, ainda é alvo de inúmeras críticas e divergências, como se passará a expor a seguir.

Para melhor ilustrar o que se pretende demonstrar no presente capítulo, mais vale uma breve transcrição de trecho do voto proferido pelo excelentíssimo magistrado da Suprema Corte Americana Anthony Kennedy no julgamento da ação Global-Tech Appliances v. SEB S.A., em maio de 2011, verbis:

"Willful blindness is not knowledge; and judges should not broaden a legislative proscription by analogy." 16

Em tradução livre, pode-se inferir que a crítica do magistrado reside na insuficiência da equiparação da ignorância deliberada ao conhecimento de fato, afirmando que não pode o órgão julgador estender a interpretação de uma disposição legislativa por meio de analogia.

Não obstante o caso acima referido se tratar de um procedimento de natureza cível, mais especificamente de um processo de propriedade intelectual, a Corte Suprema afirmou ser plenamente possível a aplicação da doutrina da cegueira deliberada em ações de natureza criminal.

Dessa forma, conforme reconhece Brian Walsh, tal interpretação acabaria por retirar a imprescindibilidade do reconhecimento do elemento subjetivo do dolo para configuração do tipo penal, o que, invariavelmente, diminuiria a proteção dos acusados de injustas punições. Nas lições do

${ }^{16}$ Global-Tech Appliances v. SEB S.A., 131 S. Ct. 2060, 2072 (2011) (Kennedy, J., dissenting). 
referido autor, a relativização do mens rea pode resultar em uma série de condenações de pessoas inocentes na seara penal. ${ }^{17}$

Ainda no ensinamento do autor, a relevância e impacto de uma condenação no âmbito criminal, com todas as agruras e dissabores que the são inerentes, são de tamanha importância que não se afigura razoável, proporcional ou ao menos democrático condenar membros de uma sociedade sem que se comprove a efetiva consciência do indivíduo acerca de um delito que apenas prevê culpabilidade decorrente do dolo. ${ }^{18}$

Tem-se como uma prática corriqueira nos Estados Unidos, representantes do órgão acusatório estatal se utilizando de meios dúbios com o fito de reduzir o seu ônus probatório e sustentar condenações se baseando no que acreditam que o acusado deveria ter conhecimento, levando em consideração as circunstâncias à época do fato.

Esta tendência em condenar réus no processo penal se valendo de uma interpretação expansiva do conceito de conhecimento do delito, satisfazendose apenas com a alta probabilidade dele e a ausência do emprego de meios para aperfeiçoá-lo, não pode passar despercebida.

E não passa.

Robin Charlow aborda em sua dissertação a problemática da aplicação da teoria da cegueira deliberada na jurisprudência americana, constatando não ser produtiva a equiparação da ignorância deliberada com o pleno conhecimento, tampouco sua equiparação com a mera imprudência. ${ }^{19}$

Nesse sentido, o uso da ignorância deliberada para configurar a tipicidade em delitos que exijam a presença do elemento subjetivo doloso, seria antijurídico e inconstitucional.

\footnotetext{
${ }^{17}$ WALSH, Brian. The Supreme Court's Willful Blindness Doctrine Opens the Door to More Wrongful Criminal Convictions. June 30, 2011.

${ }^{18}$ WALSH, Brian. The Supreme Court's Willful Blindness Doctrine Opens the Door to More Wrongful Criminal Convictions. June 30, 2011.

${ }^{19}$ Robin Charlow, Wilful Ignorance and Criminal Culpability, 70 Tex. L. Rev. 1351 (1992). P. 1355
} 
Partindo desta premissa, Robin Charlow propõe uma releitura da doutrina da cegueira deliberada. Analisando-a sob o prisma do comportamento e estado de espírito humano, a autora tenciona desvendar em qual elemento subjetivo a teoria da cegueira deliberada melhor se encaixa, para então alocá-la na hierarquia do mens rea. ${ }^{20}$

Em seu capítulo II, a referida professora e autora alude ser a doutrina uma espécie de estado mental híbrido entre o conhecimento e a mera imprudência. Ou seja, a cegueira deliberada não é um e nem o outro, mas sim um fator subjetivo intermediário e transitório entre os dois elementos. ${ }^{21}$

A problemática emerge quando da definição da punição cabível quando constatado a presença de qualquer um dos dois. É mais grave ter a plena ciência do fato ou não a ter propositalmente para evitar a responsabilização criminal?

A minuciosa análise da autora afirma ser mais reprovável a conduta daquele que possuía o efetivo conhecimento do ato e de suas consequências. Entendendo, inclusive, que por ser a cegueira deliberada um instituto que se encontra entre a cruz e a espada, sua punição deve ser correspondente à sua posição intermediária. $^{22}$

Em outras palavras, deve ser mais branda do que a punição para aquele que detinha o conhecimento pleno do ilícito, porém mais severa do que a punição para indivíduos que agiram tão somente com uma imprudência culposa.

Por outra perspectiva, mas ainda crítica ao instituto objeto do presente estudo, tem-se as explicações constantes da obra do ilustre advogado Shawn D. Rodriguez, que aborda mais especificamente a relação entre a ignorância deliberada e a negligência culpável.

\footnotetext{
${ }^{20}$ Robin Charlow, Wilful Ignorance and Criminal Culpability, 70 Tex. L. Rev. 1351 (1992). P. 1357

${ }^{21}$ Robin Charlow, Wilful Ignorance and Criminal Culpability, 70 Tex. L. Rev. 1351 (1992). P.1366/1370

${ }^{22}$ Robin Charlow, Wilful Ignorance and Criminal Culpability, 70 Tex. L. Rev. 1351 (1992). P. $1366 / 1370$
} 
O mencionado autor afirma que a principal crítica da prática forense à doutrina é a dificuldade em se estabelecer o conceito exato de "deliberada" ou willful e de distinguir o mesmo conceito do instituto da negligência. ${ }^{23}$

Se valendo de um voto proferido pelo magistrado americano Judge Posner, o autor almeja pontuar a diferença entre a atuação deliberada visando a ignorância e a mera negligência, traçando um paralelo com o comportamento de um avestruz quando diante de perigo certo e iminente.

Afigura-se indispensável para melhor compreensão da presente tese a transcrição do trecho em comento, confira-se:

\begin{abstract}
"The most powerful criticism of the ostrich instruction is, precisely, that its tendency is to allow juries to convict upon a finding of negligence for crimes that require intent. The criticism can be deflected by thinking carefully about just what it is that real ostriches do.... They are not merely careless birds. They bury their heads in the sand so that they will not see or hear bad things. They deliberately avoid acquiring unpleasant knowledge. The ostrich instruction is designed for cases in which there is evidence that the defendant, knowing or strongly suspecting that he is involved in shady dealings, takes steps to make sure that he does not acquire full or exact knowledge of the nature and extent of those dealings. A deliberate effort to avoid guilty knowledge is all the guilty knowledge the law requires" 24
\end{abstract}

Trocando em miúdos, aludiu o excelentíssimo juiz de direito ser necessária para a condenação alicerçada na doutrina da cegueira deliberada, a efetiva demonstração de que o acusado proposital e intencionalmente evitou adquirir conhecimentos indesejáveis da natureza e extensão do delito. Não bastaria apenas o descuido, ou a negligência. A teoria das instruções do avestruz foi assim nominada não por ser um vago e criativo conceito, mas porque representa o costume desta ave que não enterra sua cabeça por um descuido, mas sim por ser essa sua vontade de se esconder.

Nesta esteira de argumentação, não bastaria apenas a prova constatando a ignorância do acusado por ter sido negligente, sendo

\footnotetext{
${ }^{23}$ D. RODRIGUEZ, Shawn. Caging Careless Birds: Examining Dangers Posed By the Willful Blindness Doctrine in the War on Terror. Published by Penn Law: Legal Scholarship Repository, 2014. P. 728

${ }^{24}$ United States v. Giovannetti, 919 F.2d 1223, 1228 (7th Cir. 1990) (reversing gambling conviction in part due to an improper willful blindness instruction).
} 
necessários os elementos objetivos dando conta de que o acusado tomou atitudes e empreendeu esforços para evitar o conhecimento culpável.

A conclusão que se chega é que caso não seja perfeitamente delineada a distinção entre os institutos do conhecimento de fato do delito e a mera negligência culposa, condenações recairão sobre réus negligentes, quando o próprio tipo penal exige e tão somente permite a condenação por um ato eivado de dolo e conhecimento. ${ }^{25}$

Por fim, insta exibir e tecer breves comentários acerca das críticas expostas na obra formulada por Ira. P. Robbins, que apesar de antiga, não se afigura em hipótese alguma obsoleta.

Na ótica do supracitado autor, o principal impasse para a aplicação da doutrina da cegueira deliberada, em posição semelhante à defendida por Robin Charlow e Anthony Kennedy, está na ausência de uma previsão legal específica sobre o tema, abrindo margem aos julgadores de recorrerem a uma interpretação duvidosa para legitimar a aplicação do instituto.

O problema está na compreensão da definição de mens rea exposta no Model Penal Code ("MPC"). O autor entende que o conceito consagrado na consolidação, de ser de fato o conhecimento quando presentes a alta probabilidade de existência do evento, salvo se o agente efetivamente acreditar que o fato não se concretizará, se enquadra melhor na definição de imprudência do que na definição de real ciência do delito. ${ }^{26}$

Ao interpretar o conceito do Código de maneira indevida, ocorreriam violações frontais a princípios fundamentais da pessoa humana, mormente o da ampla defesa e do contraditório.

Isto posto, sugere o eminente professor que haja uma alteração e revisão do Model Penal Code, de modo a incluir uma definição específica

\footnotetext{
${ }^{25}$ D. RODRIGUEZ, Shawn. Caging Careless Birds: Examining Dangers Posed By the Willful Blindness Doctrine in the War on Terror. Published by Penn Law: Legal Scholarship Repository, 2014. P. 729

${ }^{26}$ Ira P. Robbins, The Ostrich Instruction: Deliberate Ignorance as a Criminal Mens Rea, 81

J. Crim. L. \& Criminology 191 (1990-1991). P. 231
} 
acerca da imprudência e da cegueira deliberada, preenchendo, desta forma, a lacuna deixada pela legislação.

É que as interpretações inadequadas do conceito de conhecimento ou knowledge disposto no Model Penal Code, podem resultar em condenações indevidas por mera negligência e imprudência. Em vista disso, deve ser construída uma definição específica do parâmetro de imprudência. Tal parâmetro alcançaria a maioria dos acusados que permanecem deliberadamente em uma situação de ignorância, mas evitaria uma interpretação expansiva, perigosa e inadequada do conceito de conhecimento. $^{27}$

Para tanto, Ira P. Robbins enumera disposições que deveriam constar da consolidação legislativa e serem oportunamente apresentadas ao tribunal do júri no caso concreto, quais sejam:

(i) Deve ser considerado antijurídico que qualquer indivíduo conscientemente ou imprudentemente importe substâncias controladas aos Estados Unidos sem a própria e devida autorização.

(ii) Considera-se que certo indivíduo agiu conscientemente quando o mesmo age sabendo que os fatos e resultados decorrentes de sua atuação existem ou existirão ou se ele está virtualmente confiante na existência ou potencial existência.

(iii) Um age de forma imprudente com relação aos fatos e resultados de sua conduta, se ele desconsiderar conscientemente um risco substancial e concreto que tais fatos e resultados existem ou existirão.

Concluindo, partindo de um padrão delineado de consciência e imprudência, a ignorância deliberada poderia ser melhor encaixada na conduta do caso em concreto, o que possivelmente instruiria de maneira mais

\footnotetext{
${ }^{27}$ Ira P. Robbins, The Ostrich Instruction: Deliberate Ignorance as a Criminal Mens Rea, 81 J. Crim. L. \& Criminology 191 (1990-1991). P. 232 e 233.
} 
satisfatória os jurados e permitiria que os juízes aplicassem um conceito mais familiar e melhor definido, evitando imposições inadequadas. ${ }^{28}$

28 Ira P. Robbins, The Ostrich Instruction: Deliberate Ignorance as a Criminal Mens Rea, 81 J. Crim. L. \& Criminology 191 (1990-1991). P. 234. 


\section{CAPÍTULO III. O DELITO DE LAVAGEM DE CAPITAIS NO BRASIL}

\section{III.I. O DESENVOLVIMENTO HISTÓRICO DO CRIME E PRINCIPAIS INOVAÇÕES LEGISLATIVAS}

O presente capítulo tem como objetivo apresentar o delito de lavagem de capitais, tal como disposto no ordenamento jurídico brasileiro, e expor como o atual conceito fora consolidado, conferindo especial atenção às alterações legislativas que ocorreram durante todo o processo.

Antes de mais nada, insta tratar da própria noção de lavagem de dinheiro, e, para tanto, utilizo a lição de Gustavo Henrique Badaró e Pierpaolo Cruz Botini que, apesar de ser um pouco extensa, pela clareza das palavras e didática dos ilustres professores, merece o presente destaque e a leitura:

Lavagem de dinheiro é o ato ou sequência de atos praticados para mascarar a natureza, origem, localização, disposição, movimentação ou propriedade de bens, valores e direitos de origem delitiva ou contravencional, com o escopo último de reinseri-los na economia formal com aparência de licitude. Nas palavras de Blanco Cordero é um "processo em virtude do qual os bens de origem delitiva se integram no sistema econômico legal com aparência de terem sido obtidos de forma lícita"29. Trata-se, em suma, do movimento de afastamento dos bens de seu passado sujo, que se inicia com a ocultação simples e termina com sua introdução no circuito comercial ou financeiro, com aspecto legítimo. ${ }^{30}$

Com o conceito internalizado, passa-se a tecer comentários e esclarecimentos acerca da criação do tipo penal e origem histórica da lavagem de dinheiro.

A lavagem de dinheiro é um tipo penal extremamente propagado e globalizado, respeitados os contornos e particularidades de cada legislação e Estado, o tipo pode ser encontrado em diversos ordenamentos jurídicos ao

\footnotetext{
${ }^{29}$ Blanco Cordero, Isidoro. El delito de blanqueo de capitales, 4. Ed. p. 107.

30 Badaró, Gustavo Henrique e Cruz Bottini, Pierpaolo. Lavagem de dinheiro: Aspectos penais e processuais penais. 3 ed. - São Paulo: Editora Revista dos Tribunais, 2016. Página 29.
} 
redor do Globo, seja sob a alcunha de lavagem de dinheiro, reciclagem de dinheiro ou branqueamento de capitais.

Nesse diapasão, Luiz Regis Prado revela que:

"A internacionalização favoreceu o desenvolvimento de um mercado global do crime, que permeia toda a sociedade. Em resposta ao desenvolvimento das trocas, a oferta e a demanda de produtos e de atos ilícitos são organizadas hoje em forma de "mercado". Outrora controlado por oligopólios confidenciais, esse "mercado do crime", que tem na internet um de seus vetores essenciais, abre-se, na atualidade, a uma ampla concorrência em todos os domínios. Assim, técnicas de lavagem de dinheiro, ativos, valores ou capitais têm evoluído, adaptando-se de modo contínuo à liberalização e à desregulamentação dos mercados, bem como à globalização financeira" 31

Pode-se considerar como um marco histórico da lavagem de dinheiro a política da Lei Seca nos Estados Unidos, onde era proibida a comercialização, transporte e importação de bebidas alcóolicas dentro do território do Estado. Tal política estatal acabou por criar um ambiente propício e frutífero para o surgimento de um mercado marginalizado e à míngua da lei.

Nas palavras e lições de Guilherme de Souza Nucci:

"A lavagem, decorrente da cultura norte americana, origina-se da década de 20, nos EUA, quando a Máfia criou várias lavanderias para dar aparência lícita a negócios ilícitos, ou seja, buscava-se justificar, por intermédio de um comércio legalizado a origem criminosa do dinheiro arrecadado." 32

No entanto, tendo em vista a pouca aceitação da população americana com a lei proibitiva, não demorou muito até que as organizações criminosas comerciantes de bebidas alcóolicas expandissem seus negócios e acumulassem considerável fortuna. ${ }^{33}$

${ }^{31}$ Regis Prado, Luiz. Direito penal econômico / Luiz Regis Prado. 7. Ed. rev. E atual. - São Paulo: Editora Revista dos Tribunais, 2016. Página 516.

${ }^{32}$ Nucci, Guilherme de Souza. Leis Penais e Processuais Penais Comentadas. - Guilherme de Souza Nucci - 10 ed. Rev. Atual. E ampl. - vol. 2 - Rio de Janeiro: Forense 2017. Página 586 33 BRAGA, Juliana Toralles dos Santos. Lavagem de dinheiro - Origem histórica, conceito e fases. In: Âmbito Jurídico, Rio Grande, XIII, n. 80, set 2010. Disponível em:

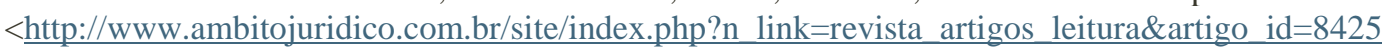


Quando da revogação da proibição, as organizações já se encontravam plenamente consolidadas e com atuação em diversos segmentos do mercado formal e informal.

Contudo, como bem preceitua Gustavo Badaró e Pierpaolo Bottini, foi apenas na década de 1980 que a repressão ao delito teve seu estopim, devido à força e ramificação de organizações criminosas atuantes à época. O desenvolvimento dessas organizações e diversificação de seus atos criminosos, em especial dos grupos que exploravam o tráfico de entorpecentes, demandava uma política criminal que abordasse a situação sob um prisma diferente. ${ }^{34}$

Isto porque, a movimentação e acúmulo de capital era tamanha, que a prisão de um ou outro integrante da operação criminosa não alteraria seu status, tampouco impossibilitaria sua continuidade.

Nesse sentido, é valiosa e construtiva a transcrição que segue:

"A sofisticada organização do comércio de drogas permitiu que seus promoventes acumulassem capital suficiente para retroalimentar sua estrutura, desenvolver redes capilarizadas e eficientes para atividades direta e indiretamente ligadas ao negócio, bem como cooptar autoridades públicas nos mais diversos setores, em manobras de aliciamento e corrupção. Percebeu-se, portanto, que a desarticulação de tais grupos exigia algo mais do que a prisão de seus membros - como já mencionado, facilmente substituíveis -, ou o uso exclusivo dos mecanismos tradicionais de repressão. Notou-se que o dinheiro é a alma da organização criminosa e seu combate passa pelo confisco dos valores que mantém operante sua estrutura. $" 35$

Isto posto, depreendeu-se que não bastaria reprimir apenas o ato criminoso, a atuação deveria ser preventiva, de modo a evitar que o dinheiro financiasse o cometimento de novos atos ilícitos e, inclusive, que o dinheiro sujo financiasse empreendimentos lícitos.

\footnotetext{
${ }^{34}$ Badaró, Gustavo Henrique e Cruz Bottini, Pierpaolo. Lavagem de dinheiro: Aspectos penais e processuais penais. 3 ed. - São Paulo: Editora Revista dos Tribunais, 2016. Página 30.

${ }^{35}$ Badaró, Gustavo Henrique e Cruz Bottini, Pierpaolo. Lavagem de dinheiro: Aspectos penais e processuais penais. 3 ed. - São Paulo: Editora Revista dos Tribunais, 2016. Página 30.
} 
E foi com esse propósito, de retirar o véu de licitude do capital oriundo de atos criminosos, mas que fora introduzido na economia formal como limpo, que se originou o termo da lavagem de dinheiro.

Para tanto, não eram suficientes apenas políticas internas e isoladas, era necessária a criação de uma grande rede interestatal que permitisse o descobrimento da atuação dos referidos grupos em outros países que não o seu originário. Tal cooperação jurídica internacional, embasada principalmente nos diplomas da Convenção de Viena, da Convenção de Palermo e da Convenção de Mérida, fora sucedida de alterações na política e legislação interna nacional, com a previsão de mecanismos para rastreamento do capital ilícito e até mesmo criação de setores judiciais especializados para o julgamento da lavagem de dinheiro. ${ }^{36}$

No Brasil, a previsão específica da lavagem de capitais foi introduzida em nossa legislação pátria com o advento da Lei 9.613 de 1998, que em seu preâmbulo traz a seguinte disposição: "Dispõe sobre os crimes de "lavagem" ou ocultação de bens, direitos e valores; a prevenção da utilização do sistema financeiro para os ilícitos previstos nesta Lei; cria o Conselho de Controle de Atividades Financeiras COAF, e dá outras providências. ”

A referida lei demonstrou a efetiva adesão do Estado Brasileiro às diversas convenções internacionais de combate à lavagem de dinheiro das quais já era signatário. ${ }^{37}$

Da leitura do texto legal em comento, tem-se que a figura da lavagem propriamente dita está presente no parágrafo primeiro do artigo primeiro, enquanto que as modalidades de participação são as constantes do parágrafo segundo do mesmo artigo. ${ }^{38}$

\footnotetext{
${ }^{36}$ Badaró, Gustavo Henrique e Cruz Bottini, Pierpaolo. Lavagem de dinheiro: Aspectos penais e processuais penais. 3 ed. - São Paulo: Editora Revista dos Tribunais, 2016. Página 31.

${ }^{37}$ Badaró, Gustavo Henrique e Cruz Bottini, Pierpaolo. Lavagem de dinheiro: Aspectos penais e processuais penais. 3 ed. - São Paulo: Editora Revista dos Tribunais, 2016. Página 31.

${ }^{38}$ Nucci, Guilherme de Souza. Leis Penais e Processuais Penais Comentadas. - Guilherme de Souza Nucci - 10 ed. Rev. Atual. E ampl. - vol. 2 - Rio de Janeiro: Forense 2017. Página 586
} 
Apesar de bem-vinda e oportuna, visto que a lex penal apenas previa os delitos de receptação ${ }^{39}$ e favorecimento real ${ }^{40}$ para indicar o desvalor de comportamentos similares, ${ }^{41}$ a Lei 9.613 de 1998 não abordava, em sua integralidade, os meios necessários para um efetivo combate do crime de lavagem de dinheiro.

Ainda que se identifique lesão à ordem econômica em certos casos, a lavagem dinheiro afigura-se como um crime que afeta a própria administração da Justiça, pois intervém diretamente na sua capacidade de exercer suas funções de investigação, processamento, julgamento e recuperação do produto oriundo do crime, não há como se conceber uma lei lacunosa. ${ }^{42}$

Vale uma ressalva acerca do conceito de administração da Justiça, que nas palavras de Gustavo Henrique Badaró e Pierpaolo Cruz Bottini deve ser considerada "sob uma perspectiva ampla, compreendendo o exercício da atividade jurisdicional e de todos os demais institutos envolvidos na solução institucional de conflitos e na apuração de fatos necessários para tal” 43

Contudo, antes de tratarmos das lacunas da Lei № 9.613 de 1998 e apresentarmos as inovações legislativas que a remodelaram, insta apresentar algumas considerações acerca das características do processo de lavagem de dinheiro, com vistas a melhor entender os conceitos e institutos que serão demonstrados ao longo do presente estudo.

O processo de lavagem de dinheiro, na linha da mais consagrada doutrina, é dividido em três fases subsequentes. Sabe-se que o delito em questão é dotado de natureza acessória, porquanto necessária a existência de um crime antecedente para tipificá-lo.

\footnotetext{
39 Art. 180 do Código Penal - Decreto Lei 2848/40

40 Art. 349 do Código Penal - Decreto Lei 2848/40

41 Badaró, Gustavo Henrique e Cruz Bottini, Pierpaolo. Lavagem de dinheiro: Aspectos penais e processuais penais. 3 ed. - São Paulo: Editora Revista dos Tribunais, 2016. Página 31.

42 Badaró, Gustavo Henrique e Cruz Bottini, Pierpaolo. Lavagem de dinheiro: Aspectos penais e processuais penais. 3 ed. - São Paulo: Editora Revista dos Tribunais, 2016. Página 85.

43 Badaró, Gustavo Henrique e Cruz Bottini, Pierpaolo. Lavagem de dinheiro: Aspectos penais e processuais penais. 3 ed. - São Paulo: Editora Revista dos Tribunais, 2016. Página 85.
} 
Portanto, tem-se que a primeira fase do processo de lavagem de capitais seria a ocultação dos valores auferidos quando do cometimento da infração penal antecedente e necessária. Conforme leciona Gustavo Badaró e Pierpaolo Bottini, a ocultação seria "o movimento inicial para distanciar o valor de sua origem criminosa, (...)sendo a fase de maior proximidade entre o produto da lavagem e a infração penal que o origina" 44

A segunda fase, na linha doutrinária de Badaró e Bottini, consistiria na dissimulação dos valores, por intermédio da realização de operações financeiras que visam dificultar o rastreamento dos bens e a própria persecução penal. ${ }^{45}$

À luz da legislação pátria, a tipicidade do delito se consolida quando consumadas a primeira e segunda fase do processo. No entanto, não se pode olvidar que a terceira fase, que seria a reinserção do capital ilícito na economia formal, é de suma importância, na medida em que sem o animus de reinserção na economia formal, não há o que se falar em lavagem de dinheiro.

Em outras palavras, não se afigura elementar do tipo a efetiva reinserção do capital sujo na economia formal, mas sim o liame subjetivo para tanto.

A resposta deve sempre ser buscada no plano subjetivo. Haverá o crime de lavagem de dinheiro quando o agente tiver a intenção direcionada de efetivamente reinserir o valor proveniente do crime na economia formal. Se assim não for, poderia se ventilar a hipótese do cometimento do crime de favorecimento real.

A lição de Gustavo Henrique Badaró e Pierpaolo Cruz Bottini nesse sentido é esclarecedora. Senão vejamos:

\footnotetext{
${ }^{44}$ Badaró, Gustavo Henrique e Cruz Bottini, Pierpaolo. Lavagem de dinheiro: Aspectos penais e processuais penais. 3 ed. - São Paulo: Editora Revista dos Tribunais, 2016. Página 32.

${ }^{45}$ Badaró, Gustavo Henrique e Cruz Bottini, Pierpaolo. Lavagem de dinheiro: Aspectos penais e processuais penais. 3 ed. - São Paulo: Editora Revista dos Tribunais, 2016. Página 32.
} 
"O tipo penal do art. $1^{\circ}$, caput, não faz menção a qualquer elemento subjetivo especial, de forma que, à primeira vista, exige-se apenas o dolo de ocultar ou dissimular os bens provenientes das infrações penais antecedentes, comportamento suficiente para afetar a administração da justiça. Mas uma interpretação teleológica faz agregar uma intenção transcendental ao comportamento típico, qual seja, a vontade de reciclar o capital por operacões comerciais ou financeiras aparentemente lícitas. Não basta a mera intenção de ocultar ou dissimular, é preciso a vontade de lavar ou reciclar o capital sujo, de usar operacões diversas para inserir os valores maculados no sistema econômico com aparência de licitude. $O$ fato desse elemento subjetivo especial não constar expressamente na redação legal não afasta sua qualidade de elementar típica. (...)

Em primeiro lugar, importa destacar que a maior parte da doutrina admite a existência de elementos típicos implícitos quando decorrentes da interpretação lógica e sistemática do ordenamento. É o que ocorre, por exemplo, nos crimes contra a honra, em relação aos quais se exige mais que o dolo da ação típica: exige-se um elemento subjetivo especial voltado à violação da honra da vítima (animus injuriandi ou difamandi), mesmo que esse elemento, essa intenção específica não esteja expressamente prevista no tipo penal. (...). Ademais, fosse exigido apenas o dolo de ocultar ou dissimular, nenhuma seria a distincão entre a lavagem de dinheiro e o favorecimento real (art. 349 do CP). O ato de 'tornar seguro o proveito do crime` - elemento típico do favorecimento real incorpora necessariamente alguma forma de encobrimento. Logo, se a ocultacão com a simples intencão de esconder o produto do crime for suficiente para a lavagem de dinheiro, não existiria mais o delito de favorecimento real, que seria abrangido em todas as suas formas pelo crime de lavagem de dinheiro. Essa identificação da lavagem com o favorecimento real impediria a punição da autolavagem, pois a simples ocultação do produto do delito por seu autor, sem intenções outras, é desdobramento natural do ato infracional, e a repressão do agente do crime por essa prática é inviável diante da inexigibilidade de conduta diversa. Como ensina a doutrina, é descabida a pretensão normativa de que o agente criminoso não busque encobrir ou ocultar de alguma forma o seu proveito. Por isso, ou se exige um elemento subjetivo especial nos crimes de lavagem de dinheiro, ou haverá uma identidade entre o tipo em análise com o favorecimento real que inviabilizará a punicão da autolavagem. (...). Em outras palavras, a diferença de penas indica uma distinção qualitativa entre a lavagem de dinheiro e o favorecimento real, um algo a mais que confere gravidade maior àquela. $\mathbf{E}$ esse algo a mais é justamente a intencão de lavar, de reciclar, de completar as três fases necessárias ao branqueamento do capital. A lavagem é uma espécie de favorecimento real qualificado pela intenção de ocultar os bens através de sua reciclagem. Não se trata mais do simples escamoteamento para tornar seguro o proveito do crime, mas da ocultacãa ou dissimulação por meio da reintegração do produto do crime à economia com aparência de licitude. ${ }^{* 46}$

\footnotetext{
${ }^{46}$ Badaró, Gustavo Henrique e Cruz Bottini, Pierpaolo. Lavagem de dinheiro: Aspectos penais e processuais penais. 2 ed. - São Paulo: Editora Revista dos Tribunais, 2013. Páginas 105/107.
} 
Nesta esteira, aclarado o conceito, contexto histórico e processo da lavagem de dinheiro, torna-se imperioso redigir alguns apontamentos a respeito das inovações legislativas trazidas ao ordenamento jurídico pátrio com a promulgação da Lei № 12.683 de 2012.

A redação original da Lei № 9.613 de 1998 previa em seu parágrafo primeiro um rol taxativo de crimes que poderiam ser considerados antecedentes da lavagem de dinheiro. Entre os mencionados na lei, pode-se destacar a presença do crime de tráfico de entorpecentes, terrorismo, contrabando ou tráfico de armas, crimes contra a Administração Pública, entre outros.

Ocorre que diversos crimes que antecediam a lavagem de dinheiro não estavam compreendidos nesse rol, de modo que a lei penal não poderia incidir sobre certos acusados culpados, vez que não haveria tipicidade no delito.

É bem verdade que, com o advento da Lei $n^{\circ} 12.683 / 12$, não mais subsiste um rol taxativo de tipos penais antecedentes, bastando que haja a ocorrência de qualquer infração penal, desde que comprovadas a existência e ligação causal da infração antecedente com o crime de lavagem de dinheiro, ${ }^{47}$ e que desta infração decorra um produto a ser lavado, o objeto material do delito.

Nas palavras de Guilherme de Souza Nucci, “em boa hora, a Lei 12.683/2012 revogou tal relação (incisos I a VIII), permitindo que qualquer infração penal (crime e contravenção) possa dar ensejo ao cometimento da lavagem de dinheiro e outros valores" 48

Outro ponto relevante que merece deliberação é a possibilidade de uma contravenção penal dar ensejo ao delito de lavagem de dinheiro. Da leitura do texto legislativo anterior, tinha-se que apenas os crimes listados taxativamente poderiam originar uma eventual lavagem de capitais. De outra

\footnotetext{
47 Badaró, Gustavo Henrique e Cruz Bottini, Pierpaolo. Lavagem de dinheiro: Aspectos penais e processuais penais. 2 ed. - São Paulo: Editora Revista dos Tribunais, 2013. Páginas 106 48 Nucci, Guilherme de Souza. Leis Penais e Processuais Penais Comentadas. - Guilherme de Souza Nucci - 10 ed. Rev. Atual. E ampl. - vol. 2 - Rio de Janeiro: Forense 2017. Página 587
} 
sorte, a nova legislação extingue esse rol e ainda inclui a possibilidade de qualquer infração penal ser antecedente ao branqueamento.

Sobre o determinado assunto, aduz Gustavo Badaró e Pierpaolo Bottini que "o critério da fixação de antecedentes na nova lei é coerente com a ideia de proteção da administração da Justiça, uma vez que o encobrimento do produto de qualquer crime é capaz de afetar o bem jurídico tutelado, independente de sua gravidade ou extensão. "49 (Grifou-se)

É válida a ressalva de que não é necessário que o fato antecedente seja ato típico, antijurídico e culpável. Basta apenas a presença dos dois primeiros fatores no ato antecedente para que se possa caracterizar o crime de lavagem de capitais. A inovação legislativa prevê que mesmo que o agente que tenha praticado o ato anterior seja não culpável ou que qualquer outro fator extinga sua punibilidade, se o ato antecedente praticado for injusto, o crime de lavagem estará configurado. ${ }^{50}$

Inclusive, é possível que a infração anterior na sua modalidade tentada seja antecedente ao crime de lavagem de dinheiro, caso a mesma seja um ato tipificado como crime. Por outro lado, se tratando de contravenção penal, tendo em vista sua tentativa não ser punível, caso o fato antecedente não se consume por circunstâncias alheias à vontade do agente, mas ainda assim provenha produto de valor econômico a ser mascarado por uma das modalidades previstas na lei de lavagem, não haverá materialidade típica.

Dessa forma, depreende-se que a Lei 12.683 de 2012 foi um necessário instrumento para a repressão e punição de agentes criminosos, vez que fora expandido o tipo penal, facilitando a persecução estatal e evitando absolvições por atipicidade.

\footnotetext{
49 Badaró, Gustavo Henrique e Cruz Bottini, Pierpaolo. Lavagem de dinheiro: Aspectos penais e processuais penais. 3 ed. - São Paulo: Editora Revista dos Tribunais, 2016. Página 100.

50 Badaró, Gustavo Henrique e Cruz Bottini, Pierpaolo. Lavagem de dinheiro: Aspectos penais e processuais penais. 3 ed. - São Paulo: Editora Revista dos Tribunais, 2016. Página 104.
} 


\section{III.II. OS ELEMENTOS SUBJETIVOS DO CRIME}

Uma questão de extrema relevância e que servirá como base para a discussão acerca da introdução da teoria da cegueira deliberada no ordenamento jurídico brasileiro é a definição do elemento subjetivo do crime de lavagem de dinheiro.

O direito penal brasileiro, regido pelo modelo do finalismo, adota dois elementos subjetivos centrais, quais sejam, o dolo e a culpa. Para melhor compreensão do presente capítulo, trataremos da definição das modalidades dolosas e culposas na linha da melhor doutrina, para então abordar sua aplicação e aceitação no crime de branqueamento de capitais.

Para os fins deste estudo, cuidaremos das definições e peculiaridades dos institutos do dolo direto, dolo eventual, dolo específico, culpa consciente e culpa inconsciente.

É consagrado e pacífico na doutrina e jurisprudência pátria que o dolo é a vontade e a consciência de se realizar os elementos presentes em determinado tipo penal. Seria o animus da pessoa humana em realizar uma conduta tipificada. ${ }^{51}$

Sobre o assunto, é necessária a atenção aos ensinamentos do eminente professor e Procurador de Justiça do Estado de São Paulo Fernando Capez, que assim leciona:

\footnotetext{
"(os elementos do dolo) são a consciência (conhecimento do fato que constitui a ação típica) e vontade (elemento volitivo de realizar esse fato) Dolo é a vontade de realizar o resultado típico ou a aceitação dos riscos de produzi-lo. (...) Para os adeptos da corrente finalista, a qual o $\mathrm{CP}^{52}$ adota, o dolo pertence à ação final típica, constituindo seu aspecto subjetivo, ao passo que a consciência da ilicitude pertence à estrutura da culpabilidade, como um dos elementos necessários à formulação do juízo de reprovação." 53
}

\footnotetext{
${ }^{51}$ Capez, Fernando. Curso de Direito Penal: Parte Geral. 3. Ed. Rev. E ampl. - São Paulo, Editora Saraiva. 2001. Página 176.

${ }^{52}$ Código Penal Brasileiro. DECRETO-LEI No 2.848, DE 7 DE DEZEMBRO DE 1940.

${ }^{53}$ Capez, Fernando. Curso de Direito Penal: Parte Geral. 3. Ed. Rev. E ampl. - São Paulo, Editora Saraiva. 2001. Página 176 e 177.
} 
O dolo é um instituto única e absolutamente psicológico, estando presente apenas no plano subjetivo de cada agente. Dentro da figura do dolo, podemos destacar o dolo direto, eventual e o específico.

$\mathrm{O}$ direto seria quando o agente quer precisamente alcançar certo resultado e, para tanto, realiza uma conduta típica. O resultado fático decorrente de sua conduta é exatamente o que o agente previa e ansiava com seu ato. É o caso de um indivíduo que busca a morte de outrem e, para atingir esse fim, atira com um projétil pérfuro-contundente em sua cabeça. Ocorrendo o resultado morte, satisfeita estaria a pretensão do autor do fato.

O dolo eventual, por sua vez, é espécie da qual o dolo indireto é gênero. Quer dizer, o dolo eventual está inserido na categoria que a doutrina intitula como dolo indireto ou indeterminado.

O dolo eventual estaria presente na situação fática onde o agente não quer diretamente o resultado, mas aceita a possibilidade de produzi-lo. ${ }^{54}$

Nas esclarecedoras palavras de Fernando Capez, "no dolo eventual o sujeito prevê o resultado e, embora não o queira propriamente atingi-lo, pouco se importa com a sua ocorrência" 55

É a situação fática onde não se quer o resultado, mas caso ele aconteça, não seria um problema suficiente para se deixar de praticar a conduta, apresentando, portanto, um grave descaso com a ocorrência.

Para concluir os comentários acerca do elemento subjetivo do dolo, apenas para fins deste estudo, insta tratar de definição de dolo específico.

Dolo específico é aquele onde há a vontade de realizar certa conduta objetivando um resultado especial presente no tipo penal. ${ }^{56}$ Nos tipos onde esteja presente um elemento específico, uma finalidade especial do agente,

\footnotetext{
${ }^{54}$ Capez, Fernando. Curso de Direito Penal: Parte Geral. 3. Ed. Rev. E ampl. - São Paulo, Editora Saraiva. 2001. Página 178.

${ }^{55}$ Capez, Fernando. Curso de Direito Penal: Parte Geral. 3. Ed. Rev. E ampl. - São Paulo, Editora Saraiva. 2001. Página 178.

${ }^{56}$ Capez, Fernando. Curso de Direito Penal: Parte Geral. 3. Ed. Rev. E ampl. - São Paulo, Editora Saraiva. 2001. Página 179.
} 
não basta, para sua caracterização e materialidade, a mera vontade e consciência do agente, deve ser demonstrada sua finalidade especial.

Para Francisco de Assis Toledo:

"Surge o dolo específico quando exige o tipo, como condição da própria tipicidade, que o agente realize a ação visando a uma determinada finalidade, diversa da vontade acrisolada à conduta. Desta sorte, no dolo específico observa-se o acréscimo de certa intenção à vontade genérica de realizar o comportamento incriminado. Há, portanto, explícita na estruturação típica do delito, uma intenção que se agrega e adiciona a outra, de cunho genérico, necessária para a constituição jurídica do crime. É a vontade que excede à do tipo, ampliando seu conteúdo subjetivo." 57

A título de exemplificação, podemos citar a hipótese do crime de falsidade ideológica, previsto no artigo 299 do Código Penal Brasileiro. Nesse tipo penal, o agente criminoso omite certa informação ou coloca informação falsa em um documento, mas é preciso que tal conduta seja tomada com o propósito específico de "prejudicar direito ou alterar a verdade sobre fato juridicamente relevante".

Outro elucidativo tipo penal é o delito de perigo de contágio venéreo (artigo 130 do Código Penal) em seu parágrafo primeiro. Aduz o texto legislativo a seguinte asserção: "se é intenção do agente transmitir a moléstia". Nesse caso, a legislação penal exige para configuração do tipo penal o especial fim de agir, a intenção na transmissão da moléstia.

Para que possamos abordar o elemento subjetivo presente na lavagem de capitais e, consequentemente, encerrar o presente capítulo, faz-se necessário a exposição de breves considerações acerca do elemento da culpa tal como compreendido pela doutrina brasileira.

A culpa não se encontra delineada na legislação brasileira, vez que seria um trabalho hercúleo, podendo se dizer até impossível, que o legislador conseguisse antever todas as condutas culposas passíveis de ocorrência que pudessem se encaixar no tipo penal. Seria exigir do legislador, por exemplo,

${ }^{57}$ De Assis Toledo, Francisco. Princípios Básicos de Direito Penal, Ed. Saraiva, 1992, pág. 154 
que indicasse todas as formas possíveis de se causar um homicídio de maneira culposa. ${ }^{58}$

Devido à referida ausência de disposição específica acerca dos contornos da culpa, para a adequação da conduta ao tipo penal, exige-se mais do que sua simples correspondência. Do ponto de vista de Fernando Capez, para a adequação típica:

"Torna-se imprescindível que se proceda um juízo de valor sobre a conduta do agente no caso concreto, comparando-a com a que um homem de prudência média teria na mesma situação. A culpa decorre, portanto, da comparação que se faz entre o comportamento realizado pelo sujeito no plano concreto e aquele que uma pessoa de prudência normal, mediana, teria naquelas mesmas circunstâncias."

Para existir o elemento da culpa e, portanto, a tipicidade da conduta, o resultado observado no plano fático deve ser previsível. Não estão acobertados pelo tipo penal os resultados que não sejam previsíveis ao homem médio. Assim, como ensina Mirabete, "só é típica a conduta culposa quando se puder estabelecer que o fato era possível de ser previsto pela perspicácia comum, normal dos homens" 60

A culpa, caso previsível, se manifesta de acordo com a inobservância de três deveres objetivos de cuidado, quais sejam, a imprudência, a negligência e a imperícia. Trataremos breve e sucintamente das três modalidades, apenas para fins de conceituação. A título de exemplificação, temos que a imprudência é um a mais, a negligência é um a menos, e a imperícia é ausência de conhecimento para tomar aquela atitude.

A imprudência é uma atuação sem o cuidado necessário, um ato comissivo que não observa a cautela necessária para sua realização.

\footnotetext{
58 Capez, Fernando. Curso de Direito Penal: Parte Geral. 3. Ed. Rev. E ampl. - São Paulo, Editora Saraiva. 2001. Página 183.

${ }^{59}$ Capez, Fernando. Curso de Direito Penal: Parte Geral. 3. Ed. Rev. E ampl. - São Paulo, Editora Saraiva. 2001. Página 183.

${ }^{60}$ Mirabete, Julio Fabbrini. Manual de Direito Penal. 3. Ed. Rev. E ampl. São Paulo, Editora Atlas. 1987. Página 144.
} 
A negligência, por sua vez, como indica Capez, é a culpa em sua forma omissiva. ${ }^{61}$ É a inobservância de um dever de cuidado antes do início da ação, resultando em um cenário lesivo e culposo.

Já a imperícia é a inaptidão técnica para o exercício de uma determinada função, ou a incapacidade e falta de conhecimento para uma atuação específica.

A partir das três supracitadas inobservâncias de um dever de cuidado, pode-se estar incurso em culpa inconsciente ou culpa consciente ou com previsão.

A culpa inconsciente, muito resumidamente, visto que não é esse o escopo da presente dissertação, é a culpa onde o resultado era previsível, porém não era previsto.

Já a culpa consciente é aquela onde o agente prevê o resultado previsível, mas acredita fielmente que o mesmo não irá acontecer. Em outras palavras, o agente tem a convicção que pode evitar o resultado lesivo decorrente de sua conduta com sua habilidade e destreza. Difere do dolo eventual porquanto nesse o agente prevê o resultado e demonstra indiferença quanto á sua ocorrência.

Um iluminador exemplo desta diferença está presente no homicídio culposo na direção de veículo automotor. É comum e cotidiano nos depararmos com exordiais acusatórias aduzindo o dolo eventual do agente que ingeriu bebida alcóolica antes de dirigir e que com sua conduta resultou na morte de outrem. Fundamenta o Parquet que a ingestão de bebida alcóolica antes de dirigir seria uma assunção do risco de causar acidentes e indiferença com os mesmos. Ocorre que tal asserção apresenta-se equivocada. Neste caso estamos diante de uma flagrante culpa consciente. O agente que ingere substâncias que alteram sua capacidade psicomotora antes de dirigir não entra no carro demonstrando indiferença caso ocorra algum acidente, tampouco busca diretamente a ocorrência do sinistro. $\mathrm{O}$ agente

\footnotetext{
${ }^{61}$ Capez, Fernando. Curso de Direito Penal: Parte Geral. 3. Ed. Rev. E ampl. - São Paulo, Editora Saraiva. 2001. Página 183.
} 
prevê o resultado, mas acredita firmemente que conseguirá evita-lo, encerrando clara e manifesta hipótese de culpa consciente.

Por conseguinte, feito este não tão breve, mas necessário introito, passemos à análise do elemento subjetivo caracterizador do delito de lavagem de capitais.

Gustavo Henrique Badaró e Pierpaolo Cruz Bottini são francos e retilíneos ao afirmar que, diferentemente do que ocorre em outros países como Espanha, Bélgica e Chile, no Brasil, o elemento subjetivo do crime se limita ao dolo. ${ }^{62}$

Da mesma forma entende Luiz Régis Prado, que assim leciona em sua obra:

\begin{abstract}
"O tipo subjetivo é representado pelo dolo (direto ou eventual), ou seja, a consciência do agente de que o bem, direito ou valor são provenientes, direta ou indiretamente, de ilícito penal (procedência delitiva dos bens), e pela vontade de ocultar ou dissimular sua natureza, origem, localização, disposição, movimentação, ou propriedade. Não se admite a forma culposa. Considerando-se desnecessária a existência de um conhecimento exato, preciso ou detalhado sobre a procedência criminosa dos bens, capitais ou valores, sendo que se conforma com um mero conhecimento superficial ou vago (conhecimento paralelo à esfera do profano), sobre a origem delitiva do bem"63
\end{abstract}

Isto posto, temos que a necessidade da demonstração do nexo doloso entre a conduta e o agente, é uma forma de proteger os acusados em um procedimento criminal, evitando a velha e proscrita responsabilidade penal objetiva. Não basta apenas o nexo causal e o dano, deve ser demonstrado o liame subjetivo do agente, seu desígnio psíquico para aquele fim. É necessária a constatação de que o agente criminoso conhecia a procedência delituosa dos bens e agiu com consciência e vontade de encobri-los. ${ }^{64}$

Certo é que dificilmente pode-se comprovar a existência do dolo sem a utilização de elementos objetivos indiciários do delito em questão. Salvo

\footnotetext{
${ }^{62}$ Badaró, Gustavo Henrique e Cruz Bottini, Pierpaolo. Lavagem de dinheiro: Aspectos penais e processuais penais. 3 ed. - São Paulo: Editora Revista dos Tribunais, 2016. Página 138.

${ }^{63}$ Regis Prado, Luiz. Direito penal econômico / Luiz Regis Prado. 7. Ed. rev. E atual. - São Paulo: Editora Revista dos Tribunais, 2016. Página 532 e 533.

${ }^{64}$ Badaró, Gustavo Henrique e Cruz Bottini, Pierpaolo. Lavagem de dinheiro: Aspectos penais e processuais penais. 3 ed. - São Paulo: Editora Revista dos Tribunais, 2016. Página 138.
} 
uma confissão do agente, o fim de agir deve ser atestado a partir da análise dos meios probatórios presentes em cada caso concreto. Porém, deve-se atentar para o fato de que a constatação por meios objetivos, não significa imputar uma responsabilidade objetiva para o delito. Nas palavras de Badaró e Bottini, "a comprovação do dolo a partir de circunstâncias objetivas não significa afastar seu caráter subjetivo. Os elementos de prova são apenas um meio para demonstrar a existência de uma relação psicológica do agente com a realidade delitiva." $" 65$

É válida a transcrição de trecho da obra de Luiz Regis Prado sobre o tema. Confira-se:

"Para demonstrar o conhecimento da origem ilícita vem a ser necessário valorar elementos indiciários que interessem ao fato, pois a lavagem de capitais constitui uma atividade criminal complexa, que faz uso de diversas técnicas e procedimentos de transformação dos proveitos do delito antecedente. Assim, por exemplo, pode-se mencionar como elementos indiciários a utilização de falsas identidades, a inexistência de relações comerciais que justifiquem certa movimentação financeira, a utilização de testas de ferro sem disponibilidade econômica real sobre tais bens, vínculo com sociedades fictícias sem qualquer atividade econômica, etc."66

Em sentido diametralmente oposto, temos o entendimento do Pretório Excelso, quando do julgamento do Habeas Corpus número 91.159, que se encontra assim ementado:

DIREITO PENAL E PROCESSUAL PENAL. HABEAS CORPUS. CRIME DE COMPETÊNCIA DO TRIBUNAL DO JÚRI. "RACHA" AUTOMOBILÍSTICO. HOMICÍDIO DOLOSO. DOLO EVENTUAL. NOVA VALORAÇÃO DE ELEMENTOS FÁTICO-JURÍDICOS, E NÃO REAPRECIAÇÃO DE MATERIAL PROBATÓRIO. DENEGAÇÃO. 1. A questão de direito, objeto de controvérsia neste writ, consiste na eventual análise de material fático-probatório pelo Superior Tribunal de Justiça, o que eventualmente repercutirá na configuração do dolo eventual ou da culpa consciente relacionada à conduta do paciente no evento fatal relacionado à infração de trânsito que gerou a morte dos cinco ocupantes do veículo atingido. 2. O Superior Tribunal de Justiça, ao dar provimento ao recurso especial interposto pelo Ministério Público do Estado de Minas Gerais, atribuiu nova valoração dos elementos fáticojurídicos existentes nos autos, qualificando-os como homicídio doloso, razão pela qual não procedeu ao revolvimento de material probatório para

\footnotetext{
${ }^{65}$ Badaró, Gustavo Henrique e Cruz Bottini, Pierpaolo. Lavagem de dinheiro: Aspectos penais e processuais penais. 3 ed. - São Paulo: Editora Revista dos Tribunais, 2016. Página 139.

${ }^{66}$ Regis Prado, Luiz. Direito penal econômico / Luiz Regis Prado. 7. Ed. rev. E atual. - São Paulo: Editora Revista dos Tribunais, 2016. Página 533.
} 
divergir da conclusão alcançada pelo Tribunal de Justiça. 3. O dolo eventual compreende a hipótese em que o sujeito não quer diretamente a realização do tipo penal, mas a aceita como possível ou provável (assume o risco da produção do resultado, na redação do art. 18, I, in fine, do CP). 4. Das várias teorias que buscam justificar o dolo eventual, sobressai a teoria do consentimento (ou da assunção), consoante a qual o dolo exige que o agente consinta em causar o resultado, além de considerá-lo como possível. 5. A questão central diz respeito à distinção entre dolo eventual e culpa consciente que, como se sabe, apresentam aspecto comum: a previsão do resultado ilícito. No caso concreto, a narração contida na denúncia dá conta de que o paciente e o co-réu conduziam seus respectivos veículos, realizando aquilo que coloquialmente se denominou "pega" ou "racha", em alta velocidade, em plena rodovia, atingindo um terceiro veículo (onde estavam as vítimas). 6. Para configuração do dolo eventual não é necessário o consentimento explícito do agente, nem sua consciência reflexiva em relação às circunstâncias do evento. Faz-se imprescindível que o dolo eventual se extraia das circunstâncias do evento, e não da mente do autor, eis que não se exige uma declaração expressa do agente. 7 . $\mathrm{O}$ dolo eventual não poderia ser descartado ou julgado inadmissível na fase do iudicium accusationis. Não houve julgamento contrário à orientação contida na Súmula 07 , do STJ, eis que apenas se procedeu à revaloração dos elementos admitidos pelo acórdão da Corte local, tratando-se de quaestio juris, e não de quaestio facti. 8 . Habeas corpus denegado." ${ }^{\prime 67}$ (Grifou-se)

Nesse alarmante decisum supracitado, observa-se uma certa objetivação do conceito de dolo. Como já dito, o dolo deve sempre ser constatado a partir do plano subjetivo de cada agente, sendo permitida sua análise através de fatos objetivos, mas nunca o substituindo por esses meros elementos de ordem objetiva. Dessa forma, não se afigura correta e técnica a argumentação da excelentíssima ministra da Suprema Corte Ellen Gracie, que no trecho grifado, aduz que o dolo deve ser extraído das circunstâncias do evento e não da mente do autor. Como já dito, os elementos objetivos podem sim auxiliar na constatação do dolo, mas jamais extinguir sua subjetividade.

A questão do dolo eventual no delito de lavagem de capitais abordaremos oportunamente, quando tratarmos da introdução da teoria da cegueira deliberada no ordenamento jurídico brasileiro.

${ }^{67}$ STF, Habeas Corpus no. 91.159/MG, Rel. Min. Ellen Gracie, DJe 02.09.2008. 


\section{III.III. A IMPOSSIBILIDADE DO CRIME DE LAVAGEM DE CAPITAIS NA MODALIDADE CULPOSA}

Como já exposto, o complexo processo do crime de lavagem de dinheiro se consuma quando finalizadas suas duas primeiras fases, placement e layering, com a presença do animus do agente em reintegrar (integration) esses valores na economia formal com uma máscara de legitimidade. ${ }^{68}$

O sujeito ativo do delito pode ser qualquer pessoa imputável, inclusive o próprio agente que cometera a infração penal antecedente, seja na modalidade de crime ou contravenção penal.

O capítulo que antecede este aduziu, paulatinamente, que o elemento subjetivo presente no delito de lavagem de capitais é o dolo, não se punindo, em hipótese nenhuma, o branqueamento na forma culposa.

Em outras palavras, nenhuma inobservância de um dever de cuidado, que resulte em uma ocultação e dissimulação de valores que posteriormente serão integrados na economia formal, será punida pelo diploma legal em comento.

A problemática emerge quando tratamos da possibilidade de uma condenação por lavagem de dinheiro em decorrência da presença do dolo eventual na psique do agente. Vale repisar, temos o dolo eventual como a consciência do resultado possível e indiferença quanto à sua consumação. Diferentemente da culpa consciente que seria a consciência do resultado possível e confiança de que ele será evitado.

Nestes termos, caso se comprove que o agente fielmente acreditava que o resultado não iria ocorrer, ou que os valores não eram de proveniência ilícita, não restaria configurado o delito de lavagem de capitais.

\footnotetext{
${ }^{68}$ Nucci, Guilherme de Souza. Leis Penais e Processuais Penais Comentadas. - Guilherme de Souza Nucci - 10 ed. Rev. Atual. E ampl. - vol. 2 - Rio de Janeiro: Forense 2017. Página 587
} 
Como aduz o próprio magistrado Sergio Fernando Moro, "de todas as dificuldades probatórias, nada se compara à prova do elemento subjetivo. Prová-lo é algo difícil em todo crime. Tal dificuldade tende a acentuar-se quanto maior for a complexidade do crime." 69

Nesse sentido, diante da complexidade do delito de lavagem de dinheiro, que se subdivide em várias fases, a constatação do elemento doloso aparenta ser extremamente penoso. Mas não é por conta da dificuldade que o mesmo deve ser relativizado. A necessidade da comprovação do dolo é uma garantia aos réus de um processo penal e corolário ao Estado Democrático de Direito. A necessidade de um análise minuciosa do elemento subjetivo do agente no caso concreto serve como uma proteção a indivíduos que estavam em uma posição de culpa consciente mas que foram acusados com base no dolo eventual.

A tênue distinção entre os dois institutos deve ser efetivamente abordada, sob pena de se submeter indivíduos às agruras de uma ação penal e, eventualmente de uma condenação criminal, quando estavam agindo de forma culposa, sendo certo que o delito é apenas e tão somente punível em sua modalidade dolosa.

Tal disposição é abraçada por nossa jurisprudência superior, conforme se depreende do recentíssimo julgado abaixo colacionado:

AGRAVO REGIMENTAL NO AGRAVO EM RECURSO ESPECIAL. AUSÊNCIA DE INDICAÇÃO DO DISPOSITIVO LEGAL TIDO POR VIOLADO. INCIDÊNCIA DA SÚMULA N. 284 DO STF. PEDIDO DE CONCESSÃO DE HABEAS CORPUS DE OFÍCIO. OCORRÊNCIA DE FLAGRANTE ILEGALIDADE. NÃO SUBSUNÇÃO DA CONDUTA DELIMITADA NO ACÓRDÃO AO CRIME DE LAVAGEM DE DINHEIRO. ORDEM CONCEDIDA, DE OFÍCIO, PARA ABSOLVER A AGRAVANTE.

1. A ausência de indicação do dispositivo de lei federal supostamente contrariado na instância ordinária caracteriza deficiência na fundamentação, o que dificulta a compreensão da controvérsia, atraindo a incidência da Súmula n. 284 do STF.

2. Os tribunais têm competência para expedir, de ofício, ordem de habeas corpus, quando, no curso de processo, verificarem que alguém sofre coação ilegal ao seu direito de locomoção.

3. Ainda que a mera ocultação, identificada como a primeira fase do ciclo de lavagem de dinheiro, caracterize o crime descrito no art.

$1^{\circ}$ da Lei n. 9.613/1998, porquanto o tipo penal não exige, para a sua consumação, as demais etapas para dissimular e reinserir os ativos na economia formal, a

\footnotetext{
${ }^{69}$ Moro, Sérgio Fernando. Crime de Lavagem de Dinheiro. São Paulo: Editora Saraiva, 2010. Página 70.
} 
conduta, para ser reconhecida como típica, deve estar acompanhada de um elemento subjetivo específico, qual seja, a finalidade de emprestar aparência de licitude aos valores ocultados, em preparação para as fases seguintes, denominadas dissimulação e reintegração.

4. Deve ser reconhecida, de ofício, a impossibilidade de subsuncão da conduta atribuída à agravante - receber depósito bancário de $R \$ 45,00$ de integrante de associacão para o tráfico de drogas - ao tipo penal relacionado ao crime de lavagem de capitais, quando tanto a sentenca condenatória quando o acórdão recorrido deixam de indicar, minimamente, o intuito da ré de dissimular a origem ilícita do valor recebido ou, ao menos, a aceitação do risco de produzir tal resultado.

5. Agravo regimental não provido. Habeas corpus concedido, de ofício, para absolver a agravante, por não constituir o fato crime de lavagem de dinheiro."70 (Grifou-se)

O Excelentíssimo Ministro Relator Rogério Schietti Cruz consagra a possibilidade da ocorrência do delito de lavagem de dinheiro quando o agente estava em situação de dolo direto ou dolo eventual, deixando claro que, apenas as modalidades dolosas mencionadas serão puníveis criminalmente.

O que deve restar claro é a absoluta impossibilidade de uma condenação criminal por lavagem de dinheiro na modalidade culposa. Devese dispender extrema atenção para a análise do elemento subjetivo no caso em concreto, de modo que a vontade de se condenar acusados - muito presente no cenário jurídico-político atual pátrio - não substitua a necessidade da demonstração do dolo do agente e que não se remodele uma culpa consciente em um dolo eventual.

A título de exemplificação da presença da culpa consciente no crime de lavagem de capitais, pode-se citar a hipótese de um indivíduo que recebe valores vultuosos e sem explicação de um familiar, acredita que os valores podem ser decorrentes de uma infração penal, mas por ter plena confiança na integridade e honestidade de seu parente, imagina que os valores teriam sido licitamente obtidos. Nesse cenário, não se poderia cogitar na condenação do agente por branqueamento de capitais, vez que o mesmo estava em uma situação de culpa consciente.

\footnotetext{
${ }^{70}$ AgRg no AREsp 328.229/SP, Rel. Ministro ROGERIO SCHIETTI CRUZ, SEXTA TURMA, julgado em 15/12/2015, DJe 02/02/2016)
} 
Enquanto no dolo eventual, o agente recebe os valores vultuosos e sem explicação, acredita que os valores decorram de uma infração penal, mas tal consciência não é o bastante para afastar sua vontade de reinseri-los na economia formal, demonstrando indiferença quanto à questão.

A diferença é sutil e leve, mas as consequências de uma errônea interpretação podem ser devastadoras. Por esse motivo que já foi dito e repisado, deve-se sempre buscar a resposta no plano subjetivo do autor do fato, mesmo que se utilize de elementos objetivos para corroborar determinada tese, a resposta final estará no plano subjetivo.

É nesse campo intermediário entre a culpa e o dolo eventual que se constata a presença da teoria da cegueira deliberada, a qual será abordada no capítulo que segue. 


\section{CAPÍTULO IV. A INTRODUÇÃO DA DOUTRINA DA CEGUEIRA DELIBERADA NO ORDENAMENTO JURÍDICO BRASILEIRO}

\section{IV.I. A CEGUEIRA DELIBERADA NA DOUTRINA E JURISPRUDÊNCIA BRASILEIRA}

A teoria da cegueira ou ignorância deliberada é algo ainda muito recente para a doutrina e jurisprudência brasileira. Encontram-se poucos capítulos e julgados dedicados à sua deliberação e melhor compreensão.

Os poucos autores que a abordam entendem que a doutrina da cegueira deliberada no delito de lavagem de capitais estaria intrinsecamente ligada à aceitação da figura do dolo eventual para configuração da tipicidade do crime.

Como já visto, o dolo eventual é aceito pela jurisprudência para conferir tipicidade ao delito de branqueamento de capitais, ainda que não esteja expressa no tipo a expressão do "deva saber". Asserção comumente disposta nos crimes que preveem a figura do dolo eventual.

A dúvida que suscita da questão é justamente o grau de consciência exigido do agente criminoso quanto à proveniência dos bens ou valores a serem lavados. Para configurar a hipótese de dolo direto, o agente que realiza a lavagem deve conhecer a procedência ilícita dos bens ou valores, por outro lado, para configuração do dolo eventual, bastaria a suspeita da procedência ilícita dos bens ou valores e aceitação deste resultado antijurídico. ${ }^{71}$

A doutrina se divide quanto à solução da questão, há quem defenda que deve haver a consciência plena e absoluta da origem suja dos bens e valores, e há quem defenda que a mera suspeita caracterizaria o dolo necessário para a tipicidade do delito.

\footnotetext{
${ }^{71}$ Badaró, Gustavo Henrique e Cruz Bottini, Pierpaolo. Lavagem de dinheiro: Aspectos penais e processuais penais. 3 ed. - São Paulo: Editora Revista dos Tribunais, 2016. Página 141.
} 
A primeira corrente é defendida e encabeçada por Gustavo Henrique Badaró e Pierpaolo Cruz Bottini, que sobre o tema, assim lecionam:

"Do ponto de vista político-criminal, a aceitação do dolo eventual impõe uma carga custosa às atividades econômicas e financeiras, pois sempre é possível duvidar da procedência de determinado capital ou dinheiro. Ainda que se afirme que o dolo eventual exige razoável suspeita da procedência ilícita dos recursos, a linha que separa a dúvida fundada do risco permitido não é suficientemente clara para conferir segurança àqueles que operam recursos alheios, como bancos. Por isso, a tipicidade subjetiva da lavagem de dinheiro na forma do caput do art. $1^{\circ}$, a nosso ver, deve ser limitada ao dolo direto., 72

No entanto, tal posição não é a predominante para a jurisprudência brasileira que, como já demonstrado ao longo do presente estudo, aceita a figura do dolo eventual para caracterização do crime de lavagem de capitais. Novamente, é necessário que a discussão gire em torno do plano subjetivo do autor, para que não seja o agente condenado sob o pretexto de estar incurso em dolo eventual, quando o mesmo tinha certeza ou segurança na procedência lícita dos bens recebidos, ainda que tenha tido uma suspeita sobre sua ilicitude, em clara hipótese de culpa consciente.

É nesse contexto que restará inserida a teoria da cegueira deliberada, que se afigura como uma espécie de dolo onde o agente cria conscientemente barreiras para evitar ter ciência e conhecimento de informações que o levem inevitavelmente a descobrir a proveniência ilícita dos bens ou valores que recebe.

A cegueira deliberada se encontra mais próxima da figura do dolo eventual, pois o agente suspeita da prática dos ilícitos, mas cria mecanismos que o auxiliam a evitar o aperfeiçoamento do seu conhecimento. ${ }^{73}$

A conceituação de Luiz Regis Prado acerca do tema é imperativa, senão vejamos:

"Por ela (cegueira deliberada), autoriza-se a atribuição de responsabilidade penal àquele que se autocoloca em situação de ignorância, evitando todo e

\footnotetext{
72 Badaró, Gustavo Henrique e Cruz Bottini, Pierpaolo. Lavagem de dinheiro: Aspectos penais e processuais penais. 3 ed. - São Paulo: Editora Revista dos Tribunais, 2016. Página 142.

${ }^{73}$ Badaró, Gustavo Henrique e Cruz Bottini, Pierpaolo. Lavagem de dinheiro: Aspectos penais e processuais penais. 3 ed. - São Paulo: Editora Revista dos Tribunais, 2016. Página 143.
} 
qualquer mecanismo apto a conceder-lhe maior grau de certeza quanto à potencial antijuricidade. Assim, no âmbito específico do delito de lavagem de capitais, o sujeito, de modo deliberado, se colocaria na situação de ignorância ("fingiria ou escamotearia desconhecimento") acerca da origem ilícita do ativo, com vistas a evitar futura responsabilização criminal."74

Nesses casos, o sujeito estaria incurso na mesma pena de quem atuou conscientemente na persecução do ilícito, equiparando-se os conceitos de conhecimento e ignorância deliberadamente criada.

O exemplo disposto na obra de Badaró e Bottini acerca da teoria da cegueira deliberada não poderia ser mais esclarecedor. Confira-se:

"É o caso do doleiro que suspeita que alguns de sues clientes podem lhe entregar dinheiro sujo para operações de câmbio e, por isso, toma medidas para não receber qualquer informação mais precisa sobre sua procedência. A intencionalidade do agente em se colocar deliberadamente em situação de ignorância afastaria o erro de tipo e legitimaria o reconhecimento do dolo"

A adoção desta teoria proporciona ao Estado uma maior facilidade na persecução e condenação de agentes que ocultam ou dissimulam valores provenientes de ilícitos com vistas à reinseri-los na economia formal. Dessa forma, presume-se o conhecimento do agente que deliberadamente se colocou em uma situação de ignorância acerca da origem suja dos bens, para condená-lo a pretexto de dolo.

A questão é problemática, vez que é preciso que se demonstre que o agente agiu propositalmente no sentido de evitar aperfeiçoar seus conhecimentos sobre o ilícito, e não com mera imprudência ou negligência. A aceitação da doutrina da cegueira deliberada no Brasil abre uma perigosa oportunidade para que se condene indivíduos a título de dolo, quando os mesmos agiam apenas de forma culposa.

A aplicação da doutrina dificulta a alegação dos defendidos de desconhecimento acerca da procedência irregular dos bens recebidos, visto que os mesmos poderão ser condenados devido à sua ignorância deliberada.

\footnotetext{
74 Regis Prado, Luiz. Direito penal econômico / Luiz Regis Prado. 7. Ed. rev. E atual. - São Paulo: Editora Revista dos Tribunais, 2016. Página 532.
} 
Para configuração da cegueira deliberadamente criada e, consequentemente, sua equiparação com o dolo eventual, deve restar cristalina como a água a intenção do agente em evitar seu conhecimento acerca dos contornos do ilícito, aliada à altamente provável existência de uma infração penal antecedente.

Não basta uma mera desconfiança, a ocorrência do ilícito deve ser provável, deve haver uma compreensão clara dos elementos objetivos do caso que levem o agente a efetivamente acreditar que ocorrera uma infração penal antecedente, a qual originou o objeto material a ser lavado. ${ }^{75}$

Apesar de a doutrina não ser pacífica e plenamente aplicada na jurisprudência brasileira, já é possível encontrar manifestações judiciais conferindo legitimidade e pertinência à cegueira deliberada, como veremos oportunamente ao longo deste capítulo. ${ }^{76}$

Nesta esteira aduz Sérgio Moro, que em sua obra de lavagem de dinheiro, defende a aplicação da teoria da cegueira deliberada caso presentes certos requisitos, in verbis:

"Desde que presentes os requisitos exigidos pela doutrina da ignorância deliberada, ou seja, a prova de que o agente tinha conhecimento da elevada probabilidade da natureza e origem criminosas dos bens, direitos e valores envolvidos e quiçá de que ele escolheu agir e permanecer alheio ao conhecimento pleno desses fatos, ou seja, desde que presentes os elementos cognoscitivo e volitivo, não se vislumbra objeção jurídica ou moral para reputá-lo responsável pelo resultado delitivo."77

Independentemente da posição que se adote, fundamental é que a doutrina seja meticulosamente estudada, abordando todos os seus contornos e possibilidades, para evitar que a mesma seja aplicada em substituição à demonstração do nexo doloso entre a conduta e o agente. ${ }^{78}$

\footnotetext{
${ }^{75}$ Badaró, Gustavo Henrique e Cruz Bottini, Pierpaolo. Lavagem de dinheiro: Aspectos penais e processuais penais. 3 ed. - São Paulo: Editora Revista dos Tribunais, 2016. Página 142.

${ }^{76}$ Badaró, Gustavo Henrique e Cruz Bottini, Pierpaolo. Lavagem de dinheiro: Aspectos penais e processuais penais. 3 ed. - São Paulo: Editora Revista dos Tribunais, 2016. Página 143

${ }_{77}^{7}$ Moro, Sérgio Fernando. Crime de Lavagem de Dinheiro. São Paulo: Editora Saraiva, 2010. Página 69.

${ }^{78}$ Badaró, Gustavo Henrique e Cruz Bottini, Pierpaolo. Lavagem de dinheiro: Aspectos penais e processuais penais. 3 ed. - São Paulo: Editora Revista dos Tribunais, 2016. Página 144.
} 
No cenário em que vivemos atualmente, é extremamente conveniente defender a acusação e as condenações com unhas e dentes. O Estado brasileiro vive um período de gritante instabilidade, onde a cada dia são descobertos novos esquemas criminosos que resultam em um prejuízo imensurável para a população. No entanto, mesmo diante de tão grave e desesperançado contexto, não pode o operador do direito se deixar levar pela emoção, principalmente os membros do Ministério Público e do Poder Judiciário. Em outras palavras, não se pode buscar a condenação a qualquer custo, não se pode normatizar o instituto do dolo, e, em hipótese alguma, pode-se violar a legislação e os princípios insculpidos na Carta Republicana de 1988 para satisfazer um interesse midiático e popular.

A equiparação do dolo à ignorância deliberadamente criada deve ser precedida de intenso debate e estudo, de modo a evitar que se extinga a necessidade de comprovação do elemento doloso para configuração de tipicidade ao delito de lavagem de capitais.

Para melhor compreensão das alegações supracitadas, vale expor o entendimento jurisprudencial do tema em questão. $\mathrm{O}$ prosseguimento do presente capítulo demonstrará os julgados de maior relevância para a aplicação da teoria da cegueira deliberada como elemento doloso no crime de lavagem de dinheiro, tecendo breves comentários e críticas às manifestações judiciais.

\section{IV.I.I. O FURTO AO BANCO CENTRAL}

O presente capítulo destina-se a expor, ainda que sucintamente, a situação fática do caso do furto ao Banco Central do Brasil, ocorrido em Fortaleza, no estado do Ceará, em agosto de 2005, e a aplicação da doutrina da cegueira deliberada pela primeiríssima vez por um órgão julgador nacional. Segundo a Polícia Federal, órgão responsável pela investigação do delito, estima-se que o prejuízo do furto tenha girado em torno de 150 
milhões de reais, fazendo deste caso o maior assalto a banco ocorrido no Brasil em toda sua história. ${ }^{79}$

O modus operandi do furto fora extremamente trabalhado e deliberado entre os componentes do grupo criminoso, que alugaram uma casa próxima ao Banco Central sob o pretexto de abrir uma empresa especializada na comercialização de grama sintética. Com conhecimentos de engenharia e da estrutura interna do banco, os criminosos escavaram um extenso túnel que os permitiu subtrair a vultuosa quantia acima mencionada.

A exordial acusatória aduziu estarem caracterizados no caso os delitos de furto qualificado, formação de quadrilha, ocultação de bens e valores, uso de documento falso, falsa identidade, posse ilegal de arma de fogo de uso restrito e lavagem de dinheiro. Além dos suspeitos envolvidos no cometimento do crime, o Ministério Público Federal entendeu por bem denunciar dois sócios de uma revendedora de automóveis local como incursos no crime de lavagem de capitais, vez que logo após o furto, alguns membros do grupo criminoso teriam se dirigido à concessionária de veículos e adquirido onze automóveis mediante pagamento em espécie, em um valor total aproximado de um milhão de reais.

Quando do julgamento do processo, entendeu o magistrado a quo que os donos da concessionária estariam de fato sujeitos à reprimenda prevista na Lei $n^{\circ} 9.613$ de 1998, porquanto deveriam saber da procedência delituosa dos bens. Aplicando a teoria da cegueira deliberada e a equiparando com a figura do dolo eventual, o juiz sentenciante, apesar de afirmar que não havia elementos objetivos constatando a ciência plena dos acusados quanto à origem dos bens, entendeu por bem condená-los diante da alta probabilidade e suspeita da proveniência suja do valor investido nos automóveis.

Contudo, consagrando os princípios fundamentais constitucionais mais basilares, e em completa atenção ao Estado Democrático de Direito, o acórdão de apelação proferido pelo EGRÉGIO TRIBUNAL REGIONAL FEDERAL

\footnotetext{
${ }^{79}$ Disponível em: https://noticias.terra.com.br/brasil/policia/sp-policia-prende-mentor-de-furto-aobanco-central-em
} 
DA $5^{\mathrm{a}}$ REGIÃO reverteu esse decisum condenatório, ao argumento de que não estaria prevista na legislação atinente a possibilidade de tipicidade do delito por dolo eventual. Ou seja, como o magistrado de primeira instância aduziu estar tipificado o delito em razão da teoria da cegueira deliberada, que quando muito, pode apenas ser equiparada ao dolo eventual, a condenação não poderia ser mantida, visto que o delito de lavagem de capitais apenas comportava a figura do dolo direto.

O r. acórdão, por ser muito extenso não será integralmente transcrito, por outro lado, o trecho de maior relevância para o presente estudo restou vazado nos seguintes termos:

"2.4- Imputação do crime de lavagem em face da venda, por loja estabelecida em Fortaleza, de 11 veículos, mediante o pagamento em espécie: a transposição da doutrina americana da cegueira deliberada (willful blindness), nos moldes da sentença recorrida, beira, efetivamente, a responsabilidade penal objetiva; não há elementos concretos na sentença recorrida que demonstrem que esses acusados tinham ciência de que os valores por ele recebidos eram de origem ilícita, vinculada ou não a um dos delitos descritos na Lei ${ }^{\circ}{ }^{\circ}$ 9.613/98. O inciso II do PARÁGRAFO $2 .^{\circ}$ do art. $1 .^{\circ}$ dessa lei exige a ciência expressa e não, apenas, o dolo eventual. Ausência de indicação ou sequer referência a qualquer atividade enquadrável no inciso II do PARÁGRAFO

- Não há elementos suficientes, em face do tipo de negociação usualmente realizada com veículos usados, a indicar que houvesse dolo eventual quanto à conduta do art. $1 .^{\circ}$, PARÁGRAFO $1^{\circ}$, inciso II, da mesma lei; na verdade, talvez, pudesse ser atribuída aos empresários a falta de maior diligência na negociação (culpa grave), mas não, dolo, pois usualmente os negócios nessa área são realizados de modo informal e com base em confiança construída nos contatos entre as partes." 80

Como pode se depreender do julgado acima colacionado, o eminente Desembargador Relator Rogério Fialho entendeu que a importação da doutrina da cegueira deliberada no caso em concreto encerraria grave hipótese de responsabilidade penal objetiva que, como cediço, é absolutamente inadmissível no ordenamento jurídico pátrio, na medida em que o direito criminal brasileiro está alicerçado no princípio da

80 (PROCESSO: 200581000145860, ACR5520/CE, DESEMBARGADOR FEDERAL ROGÉRIO FIALHO MOREIRA, Segunda Turma, JULGAMENTO: 09/09/2008, PUBLICAÇÃO: DJ 22/10/2008 - Página 207) 
responsabilidade penal subjetiva, que inclusive encontra previsão legal expressa no artigo 18 do Decreto-Lei № 2.848, de 7 de dezembro de 1940, que assim dispõe:

“ Art. 18 - Diz-se o crime:

\section{Crime doloso}

I - doloso, quando o agente quis o resultado ou assumiu o risco de produzi-lo;

\section{Crime culposo}

II - culposo, quando o agente deu causa ao resultado por imprudência, negligência ou imperícia.

Parágrafo único - Salvo os casos expressos em lei, ninguém pode ser punido por fato previsto como crime, senão quando o pratica dolosamente."

Certo é que atualmente o entendimento não é esse. A figura do dolo eventual é plenamente aceita pela jurisprudência pátria, mormente devido às alterações promovidas pela promulgação da Lei No 12.683 de 2012. Contudo, não se pode jamais estender tal posicionamento de modo a abarcar a figura da culpa no delito de lavagem de capitais. A utilização da teoria da cegueira deliberada equiparada ao dolo eventual no crime em comento deve ser efetivamente analisada, de modo a evitar que o conceito se estenda a casos de lavagem de dinheiro imprudente ou negligente, onde o agente por culpa não teria percebido os riscos de sua conduta. ${ }^{81}$

Apesar de ser considerado o leading case acerca da importação da doutrina da cegueira deliberada pela jurisprudência brasileira, o furto ao Banco Central do Brasil não é a manifestação judicial mais emblemática do tema em questão. Tal posição é reservada ao Supremo Tribunal Federal, quando do julgamento da Ação Penal n 470, ou como popularmente conhecido o caso do "Mensalão", um dos processos mais alegóricos e midiáticos da história do país.

\footnotetext{
81 Badaró, Gustavo Henrique e Cruz Bottini, Pierpaolo. Lavagem de dinheiro: Aspectos penais e processuais penais. 3 ed. - São Paulo: Editora Revista dos Tribunais, 2016. Página 146.
} 


\title{
IV.I.II. 0 JULGAMENTO DA AÇÃO PENAL 470 ("MENSALÃO")
}

\begin{abstract}
"A admissão do dolo eventual decorre da previsão genérica do art. 18, I, do Código Penal, jamais tendo sido exigida previsão específica ao lado de cada tipo penal específico. O Direito Comparado favorece o reconhecimento do dolo eventual, merecendo ser citada a doutrina da cegueira deliberada construída pelo Direito anglo-saxão (willful blindness doctrine). Para configuração da cegueira deliberada em crimes de lavagem de dinheiro, as Cortes norte-americanas têm exigido, em regra, (i) a ciência do agente quanto à elevada probabilidade de que os bens, direitos ou valores envolvidos provenham de crime, (ii) o atuar de forma indiferente do agente a esse conhecimento, e (iii) a escolha deliberada do agente em permanecer ignorante a respeito de todos os fatos, quando possível a alternativa. Nesse sentido, há vários precedentes, como US vs. Campbell, de 1992, da Corte de Apelação Federal do Quarto Circuito, US vs. Rivera Rodriguez, de 2003, da Corte de Apelação Federal do Terceiro Circuito, US vs. Cunan, de 1998, da Corte de Apelação Federal do Primeiro Circuito. Embora se trate de construção da common law, o Supremo Tribunal Espanhol, corte da tradição da civil law, acolheu a doutrina em questão na Sentencia 22/2005, em caso de lavagem de dinheiro, equiparando a cegueira deliberada ao dolo eventual, também presente no Direito brasileiro, $\mathrm{Na}$ hipótese sub judice, há elementos probatórios suficientes para concluir por agir doloso - se não com dolo direto, pelo menos com dolo eventual -,quanto a Pedro Corrêa, Pedro Henry, Valdemar da Costa Neto, Jacinto Lamas, estes dois na extensão do voto do Revisor, Enivaldo Quadrado e a Breno Fischberg. Estendo essa conclusão a Jacinto Lamas, na esteira dos votos do Relator e do Revisor, por sua posição relevante de tesoureiro do PL e envolvimento específico nos atos de lavagem consistentes na realização dos saques em espécie por interposta pessoa. Já quanto a João Cláudio Genu, não tenho a mesma segurança em reconhecer o agir doloso. Estando ele em posição subordinada, inviável concluir, com a certeza necessária a uma condenação criminal, que informado o seu agir por dolo direto ou eventual, especificamente quanto à ciência da procedência criminosa dos valores recebidos e repassados aos parlamentares. Então, presente dúvida razoável, há de ser absolvido." ${ }^{82}$ (Grifou-se)
\end{abstract}

A partir da leitura do bem fundamentado voto da ilustre ministra da Corte Constitucional Rosa Weber, pode-se perceber a presença, ainda que de forma residual, da teoria da cegueira deliberada na jurisprudência brasileira. Contudo, antes de abordarmos a aplicação da teoria no caso em concreto, necessário se faz explicitar a origem e contornos do processo

\footnotetext{
${ }^{82}$ Ação Penal 470, STF, Rel. Ministro Joaquim Barbosa. Trecho do voto da Min. Rosa Weber. Fl. 1273 do acórdão
} 
criminal em questão, para facilitar a compreensão do instituto exposto ao longo do presente capítulo.

A Ação Penal 470, ou Mensalão, teve seu estopim com as revelações do então Deputado Federal Roberto Jefferson que admitiu a existência de um extenso e profundo esquema de pagamento de facilitações e vantagens indevidas a parlamentares aliados ao governo da situação à época. Nos termos descritos por Roberto Jefferson, o pagamento das vantagens era realizado e organizado pelo tesoureiro do Partido dos Trabalhadores à época, Delúbio Soares.

Quando do oferecimento da incoativa acusatória pela Procuradoria Geral da República, quarenta indivíduos suspeitos se encontraram denunciados, entre os quais pode-se destacar o então Ministro-Chefe da Casa Civil José Dirceu e o presidente do Partido dos Trabalhadores, José Genoíno. O então Presidente da República, Luiz Inácio Lula da Silva, não teve seu nome denunciado, tendo, inclusive, conseguido a reeleição em 2006.

Após o devido trâmite processual, o Supremo Tribunal Federal, em agosto 2007, após longos dois anos de deliberação, entendeu por bem receber a denúncia ministerial, tendo em vista a presença de indícios de autoria e materialidade, e instaurou a Ação Penal em face dos quarenta envolvidos no escândalo. Quando do julgamento do feito, 27 dos envolvidos se encontraram condenados pelo cometimento de diversos crimes, entre os quais, o delito de lavagem de capitais, objeto do presente estudo.

O caso do Mensalão afigura-se indispensável para a discussão da teoria da cegueira deliberada no ordenamento jurídico brasileiro, vez que foi a primeira vez que nossa Corte Suprema se debruçou sobre o tema. Entre os ministros que entenderam por bem importar o conceito, pode-se destacar a posição adota pela já citada Ministra Rosa Weber e pelo decano do Supremo, Ministro Celso de Mello.

Não obstante a condenação por lavagem de dinheiro dos réus Paulo Rocha e João Magno, ambos deputados federais, e do ex-ministro de transportes Anderson Adauto, ter se dado devido à presença do dolo direto 
dos acusados, nas palavras do ministro, o mesmo entendeu que seria possível também a condenação com base na cegueira deliberada equiparada ao dolo eventual, conforme pode-se depreender do trecho que segue:

"Admito a possibilidade de configuração do crime de lavagem de valores, mediante o dolo eventual, exatamente com apoio no critério denominado por alguns como 'teoria da cegueira deliberada', que deve ser usado com muita cautela" 83

O ministro demonstrou que, conforme já esclarecido ao longo do presente trabalho, nos casos de cegueira deliberada, o agente finge não perceber determinada situação de ilicitude para alcançar a vantagem pretendida e evitar uma responsabilização na seara penal. Apesar de restar constatada a presença do dolo direto na situação fática dos antigos deputados e ministro dos transportes, caso a conduta dos réus fosse de deliberadamente evitar a consciência do delito, criando efetivas barreiras para impedir o aperfeiçoamento dos fatos, os três se encontrariam igualmente condenados. 84

Da mesma sorte, entendeu a ministra Rosa Weber, em seu voto acima transcrito, a possibilidade da transposição da teoria da ignorância deliberada ao direito penal brasileiro, caso preenchidos três requisitos, quais sejam, (i) a ciência do agente quanto à elevada probabilidade de que os bens, direitos ou valores envolvidos provenham de crime, (ii) o atuar de forma indiferente do agente a esse conhecimento, e (iii) a escolha deliberada do agente em permanecer ignorante a respeito de todos os fatos, quando possível a alternativa. ${ }^{85}$

Em posição semelhante, lecionam Gustavo Henrique Badaró e Pierpaolo Cruz Bottini, in verbis:

"A cegueira deliberada somente é equiparada ao dolo eventual nos casos de criação consciente e voluntária de barreiras que evitem o conhecimento de indícios sobre a proveniência ilícita dos bens. Como afirma BLANCO

\footnotetext{
${ }^{83}$ Disponível em http://www.stf.jus.br/portal/cms/verNoticiaDetalhe.asp?idConteudo=221405

${ }^{84}$ Disponível em http://www.stf.jus.br/portal/cms/verNoticiaDetalhe.asp?idConteudo=221405

85 Ação Penal 470, STF, Rel. Ministro Joaquim Barbosa. Trecho do voto da Min. Rosa Weber. Fl. 1273 do acórdão.
} 
CORDERO $^{86}$, a cegueira deliberada não é apenas uma situação objetiva, mas exige sempre por parte do agente uma suspeita anterior de que um ato delitivo possa ocorrer relacionado ao seu âmbito de atuação, a probabilidade de que tal ato ocorra, e a evitabilidade, ou seja, que seja possível ao agente impedir a continuidade do curso causal da lavagem de dinheiro." ${ }^{87}$

Como bem pontuaram os excelentíssimos ministros, a adoção da teoria deve ser precedida de muita cautela, em completa atenção aos seus requisitos caracterizadores, e evitando uma responsabilização penal objetiva dos acusados por lavagem de dinheiro. Vale repisar, não pode o livre convencimento do magistrado julgador ser alicerçado pela emoção e desejo de punir, os elementos objetivos devem dar a mais completa clareza de que o acusado estava em uma situação de dolo, e não de mera desídia ou imprudência.

A título de curiosidade, confira-se abaixo recentíssimo julgado do Tribunal Regional Federal da $3^{\text {a }}$ Região, que afastou a incidência da teoria da cegueira deliberada no caso em concreto, vez que a conduta do agente não teria preenchido os requisitos mencionados pela Excelentíssima Ministra Rosa Weber, in verbis:

PENAL. PROCESSUAL PENAL. MOEDA FALSA. ARTIGO $289, \S 1^{\circ}$ DO CÓDIGO PENAL. AUSÊNCIA DE PROVA SUFICIENTE PARA A CONDENAÇÃO. DOLO NÃO COMPROVADO. AFASTADA A TEORIA DA CEGUEIRA DELIBERADA. IN DÚBIO PRO REO. ARTIGO 386, INCISO VII, DO CÓDIGO DE PROCESSO PENAL. ABSOLVIÇÃO MANTIDA CONFORME SENTENÇA DE PRIMEIRO GRAU. 1. Materialidade e autoria delitivas comprovadas. 2. Ausência de prova quanto ao dolo. 3. Em particular, a análise das provas colhidas em juízo - interrogatório do réu e declarações das testemunhas desaconselham a prolação de um édito condenatório, pairando dúvidas fundadas acerca da atitude do acusado se foi dolosa ou não, o que configura ônus da acusação a sua demonstração. 4. Com efeito, o crime de moeda falsa, em suas várias modalidades, exige o dolo genérico para sua configuração, inexistindo a figura culposa e deve ser apurado por meio do conjunto probatório que envolve o caso, de modo que não deve restar dúvidas acerca da intenção do agente. De modo que afasto a alegação da acusação de que o acusado teria agido em uma cegueira deliberada a fim de justificar a presença do dolo, ao menos o eventual, tendo em vista que neste, o agente prevê a possibilidade do resultado lesivo e assume o risco do dano que porventura venha a ocorrer. Ora, faz-se necessária uma

\footnotetext{
86 Apud. Blanco Cordero, Isidoro. El delito de blanqueo, 4. Ed., página 833.

${ }^{87}$ Badaró, Gustavo Henrique e Cruz Bottini, Pierpaolo. Lavagem de dinheiro: Aspectos penais e processuais penais. 3 ed. - São Paulo: Editora Revista dos Tribunais, 2016. Página 146.
} 
percepção evidente das circunstâncias bem como a consciência acerca dos elementos do tipo, sendo que a mera imprudência ou desídia ou descuidado por parte do acusado não é suficiente para a caracterização do dolo eventual. 5. A respeito da aludida teoria também conhecida como "Evitação da Consciência", destaca-se o entendimento do Ministro Celso de Melo proferido na ocasião do julgamento da AP 470: (...) em que o agente fingiria não perceber determinada situação de ilicitude para, a partir daí, alcançar vantagem prometida". (AP 470/MG, rel. Min. Joaquim Barbosa, 27, 29 e 30.8.2012 - Informativo 677, STF ). Inclusive no mesmo julgamento da AP 470, a Ministra Rosa Weber em seu voto destacou os critérios para aplicação da teoria da cegueira deliberada: i) a ciência do agente quanto à elevada probabilidade de que bens, direitos ou valores provenham de crimes; ii) o atuar de forma indiferente a esse conhecimento; iii) a escolha deliberada do agente em permanecer ignorante a respeito de todos os fatos, quando possível a alternativa (folha 1.273 do acórdão). 6 . Nota-se que não restou comprovado nos autos que o acusado teria agido de forma consciente e voluntária para se criar empecilhos a evitar o conhecimento da proveniência ilícita das cédulas de dólares falsos contidos no envelope, diante de sua condição de moto boy/office boy acostumado a realizar entregas rotineiramente de envelopes para diversas pessoas sem o hábito de abri-los, de modo que o acusado não percebeu que poderia com sua conduta facilitar a prática de infrações penais, ou seja, afasta-se a incidência da teoria da cegueira deliberada no presente caso. Assim, como não há prova de que o acusado teve conhecimento de que o valor que iria receber pela entrega do envelope possivelmente derivaria de uma prática delitiva, não há falar-se em aplicação da willful blindness doctritne, ressaltando-se que o crime de moeda falsa não é punido a título de culpa. ${ }^{88} 7$. Diante da inexistência de prova penal convincente e necessária a autorizar a formulação de um juízo de certeza quanto à culpabilidade do acusado no que tange à imputação penal e havendo dúvida razoável quanto ao dolo, a absolvição deve ser mantida, com a aplicação do princípio in dubio pro reo. 8 . Apelação do Ministério Público Federal desprovida. Mantida absolvição." ${ }^{89}$ (Grifou-se)

Como bem ressaltam, Badaró e Bottini, "nem todas as situações identificadas pela doutrina estrangeira como cegueira deliberada são equiparáveis ao dolo, ponderação importante para a lavagem de dinheiro, que apenas admite essa modalidade de tipicidade subjetiva." 90

\footnotetext{
${ }^{88}$ Sem a alta probabilidade da ocorrência do delito antecedente, e sem o elemento objetivo dando conta de que o agente teria criado barreiras propositalmente para evitar aperfeiçoar seu conhecimento sobre o ilícito de que suspeitava, não há o que se falar de cegueira deliberada e equiparação com o dolo eventual. O caso, apesar de não tratar de lavagem de capitais, é de suma importância para o presente estudo, visto que o crime de moeda falsa também não comporta a figura da responsabilidade culposa, que, reitere-se, deve estar expressamente prevista no tipo.

${ }^{89}$ Ap. 00140321320164036181, DESEMBARGADOR FEDERAL MAURICIO KATO, TRF3 QUINTA TURMA, e-DJF3 Judicial 1 DATA:07/12/2017

${ }^{90}$ Badaró, Gustavo Henrique e Cruz Bottini, Pierpaolo. Lavagem de dinheiro: Aspectos penais e processuais penais. 2 ed. - São Paulo: Editora Revista dos Tribunais, 2013. Página 144.
} 
Concluindo, foi essa a primeira vez que o instituto fora utilizado pelo Supremo Tribunal Federal, dando ensejo à maior aplicação da doutrina por tribunais inferiores, como se verá a seguir a partir da análise de certas decisões proferidas por ocasião dos processos criminais decorrentes da famigerada operação da polícia federal, a Lava-Jato.

\section{IV.I.III. AS DECISÕES DA 13ㄹ VARA FEDERAL DE CURITIBA}

A aplicação da teoria da cegueira deliberada vem sendo frequentemente utilizada pelos magistrados responsáveis pelo processamento e julgamento dos feitos decorrentes da Operação Lava-Jato, entre os quais pode se destacar os juízes Sérgio Fernando Moro e Marcelo da Costa Bretas, atuantes nas Seções Judiciárias de Curitiba e do Rio de Janeiro, respectivamente.

A doutrina importada do sistema do common law, com base em dados levantados pela Folha de São Paulo ${ }^{91}$, fundamentou até o início do corrente ano, treze sentenças condenatórias em um universo de cento e vinte um indivíduos condenados por lavagem de dinheiro. Nesses casos, baseia-se o magistrado no fato de que apesar de não restar comprovada a ciência plena do ilícito que resultou no objeto material a ser lavado, os acusados tinham como extremamente provável a ocorrência da infração antecedente, e escolheram nada fazer para aprofundar seu conhecimento.

A questão, como já exaustivamente exposto ao longo do estudo, é cercada de intenso debate e divergência. Há quem entenda que a aplicação da teoria da cegueira deliberada seria uma forma de cercear a defesa dos acusados, visto que não seriam aceitas suas alegações de ignorância acerca do crime anterior, mesmo o delito expressamente exigindo a prova do dolo direto na ocultação e dissimulação dos valores provenientes de ilícitos. Spencer Toth Sydow, em entrevista à Folha de São Paulo, aduz que "A teoria

91 Disponível em: http://www1.folha.uol.com.br/poder/2017/12/1946478-teoria-da-cegueiradeliberada-ampara-condenacoes-na-lava-jato.shtml 
da cegueira deliberada desequilibra a balança da Justiça em favor da acusação, porque estreita o caminho para a defesa. Com ela, o acusado não pode alegar a ignorância, e o Estado não precisa buscar a prova" $" 92$

Por outro lado, não é esse o entendimento majoritário demonstrado pela jurisprudência brasileira. Para fins deste posicionamento, analisaremos as decisões proferidas pelo magistrado Sergio Moro, onde foi legitimado o uso da doutrina da cegueira deliberada.

Como forma de introduzir o tema, mais vale a transcrição de trecho da sentença proferida pelo ilustríssimo magistrado, que determinou a condenação de Eduardo Musa, Pedro Barusco, João Santana, entre outros, em um dos casos mais simbólicos da Operação Lava-Jato. Confira-se:

“370. São aqui também pertinentes as construções do Direito anglosaxão para o crime de lavagem de dinheiro em torno da "cegueira deliberada" ou "willful blindness" e que são equiparáveis ao dolo eventual da tradição do Direito Continental europeu. Escrevi longamente sobre o tema em obra dogmática (MORO, Sergio Fernando. Crime de lavagem de dinheiro. São Paulo, Saraiva, 2010). 371. Em síntese, aquele que realiza condutas típicas à lavagem, de ocultação ou dissimulação, não elide o agir doloso e a sua responsabilidade criminal se escolhe deliberadamente permanecer ignorante quanto à natureza dos bens, direitos ou valores envolvidos na transação, quando tinha condições de aprofundar o seu conhecimento sobre os fatos. 372 . A doutrina da cegueira deliberada, apesar de constituir construção da common law, foi assimilada pelo Supremo Tribunal Espanhol (STE), ou seja, corte da tradição da civil law, em casos de receptação, tráfico de drogas e lavagem, dentre outros. Por todos, transcrevo parcialmente trecho de decisão do Supremo Tribunal Espanhol na STS 33/2005, na qual a ignorância deliberada foi assimilada ao dolo eventual." $" 93$

Nos termos do magistrado sentenciante, não merece guarida a alegação de que é incabível a equiparação da teoria da cegueira deliberada com a figura do dolo eventual, tampouco pode-se admitir a ausência de nexo doloso quando comprovada a atuação positiva do agente para se manter em uma posição de ignorância e desconhecimento.

\footnotetext{
92 Disponível em: http://www1.folha.uol.com.br/poder/2017/12/1946478-teoria-da-cegueiradeliberada-ampara-condenacoes-na-lava-jato.shtml

93 Sentença Proferida na Ação Penal 501340559.2016.4.04.7000/PR. Página 103 a 106. Disponível em: https://www.conjur.com.br/dl/moro-condena-joao-santana-cegueira.pdf
} 
Com efeito, Sergio Moro embasa sua atuação na necessidade de se condenar aqueles que reiteradamente praticam os delitos de lavagem, que, por ser um delito de extrema complexidade, exige uma extensão do conceito do dolo e do conhecimento. Senão vejamos trecho da mesma sentença:

"380. Caso exigido o conhecimento circunstancial do crime antecedente e o dolo direto, condutas graves de lavagem de dinheiro, envolvendo especialmente profissionais do ramo de lavagem ou agentes dedicados habitualmente a sua prática, remanesceriam impunes. 381. Esclareça-se que não se trata de dolo sem representação. $O$ agente representa a elevada probabilidade de que os valores envolvidos constituem produto de crime e que, se persistir na conduta de ocultação ou dissimulação, corre o risco de lavar produto de crime. $\mathrm{O}$ agente não é punido pela ignorância deliberada, ou seja, por sua escolha em não aprofundar o seu conhecimento. Esse elemento serve apenas como prova da representação da probabilidade da origem criminosa dos valores, ou seja, ele escolhe não aprofundar o seu conhecimento, pois de antemão tem presente o risco do resultado delitivo e tem a intenção de realizar a conduta, aceitando o resultado delitivo como probabilidade. ${ }^{94}$

Isto posto, conclui o magistrado que:

“382. Certamente, não é a sentença judicial o melhor espaço para longas digressões dogmáticas a respeito de institutos de Direito Penal. Sem embargo do que mais se poderia escrever, é possível concluir que, desde que se tenha prova de que o agente tinha conhecimento da elevada probabilidade da natureza e origem criminosas dos bens, direitos e valores envolvidos nas condutas de ocultação e de dissimulação e de que ele escolheu agir e permanecer alheio ao conhecimento pleno desses fatos, mesmo tendo condições de aprofundar seu conhecimento, ou seja, desde que presentes os elementos cognoscitivo e volitivo, é possível e necessário reconhecer a prática do crime de lavagem por dolo eventual diante da previsão geral do art. 18, I, do CP e considerando a sua progressiva admissão pelas Cortes brasileiras." ${ }^{\circ 5}$

Vale exaltar a ressalva feita pelo próprio magistrado sentenciante em seu veredito condenatório. Como pode se ver, os acusados não restaram condenados por conta de sua ignorância deliberada, visto que tal situação poderia se confundir com uma imprudência ou negligência. Aduz Sergio Moro que a ignorância deliberada apenas corrobora o fato da alta

\footnotetext{
${ }^{94}$ Sentença Proferida na Ação Penal 501340559.2016.4.04.7000/PR. Página 103 a 106. Disponível em: https://www.conjur.com.br/dl/moro-condena-joao-santana-cegueira.pdf ${ }^{95}$ Sentença Proferida na Ação Penal No 501340559.2016.4.04.7000/PR. Página 103 a 106. Disponível em: https://www.conjur.com.br/dl/moro-condena-joao-santana-cegueira.pdf
} 
probabilidade da origem criminosa dos bens e valores, e de que o agente assumiu o risco e não demonstrou preocupação com o resultado delitivo.

Em outras palavras, a tipicidade do delito e a consequente condenação, se deram pela presença do dolo eventual do agente, servindo a teoria da cegueira deliberada tão somente como método de equiparação.

Contudo, não é todo e qualquer caso de lavagem de capitais que faz jus à aplicação da teoria da cegueira deliberada, como pode-se depreender da célebre sentença proferida por Sérgio Moro no processo que decretou a condenação do ex-Presidente da República, Luiz Inácio Lula da Silva. Senão vejamos:

"914. Sem que haja melhor prova de que os executivos tinham ciência de que a manutenção do imóvel indevidamente em nome da OAS Empreendimentos e de que a realização das reformas com ocultação do real beneficiário tinham origem em um acerto de corrupção, não podem eles responder por crimes de lavagem. 915. Não reputo aqui pertinente as construções em torno da doutrina da cegueira deliberada no crime de lavagem dinheiro e da responsabilização por dolo eventual, pois elas também exigem a presença de um contexto que torne pelo menos de elevada probabilidade o conhecimento da origem criminosa dos recursos utilizados em uma transação de lavagem. Considerando as peculiaridades do caso, com o repasse da vantagem indevida atráves de negócios imobiliários, é possível que tenham cogitado outras hipóteses razoáveis para justificar as ordens recebidas de José Adelmário Pinheiro Filho, até mesmo de que se tratava de um presente do Grupo OAS para o exPresidente." 96

A posição de Sergio Moro não é isolada e única na jurisprudência. $\mathrm{O}$ próprio Tribunal Regional Federal da $4^{\mathrm{a}}$ Região, instância responsável pela apreciação de eventuais recursos interpostos contra decisões da $13^{\mathrm{a}}$ Vara Federal de Curitiba, vem admitindo a possibilidade de aplicação da teoria da cegueira deliberada em procedimentos criminais. Veja-se julgado publicado em março do corrente ano:

"PENAL E PROCESSO PENAL. CONTRABANDO. ARTIGO 334-A, "CAPUT" DO CÓDIGO PENAL. INSTALAÇÃO CLANDESTINA DE RÁDIO TRANSCEPTOR. ART. 70 DA LEI No 4.117/62.ARTIGO 311 DO CÓDIGO DE TRÂNSITO BRASILEIRO. RECEPTAÇÃO QUALIFICADA. ART. $180, \S \S 1^{\circ}$ E $2^{\circ}$, DO CÓDIGO PENAL. MATERIALIDADE E AUTORIA COMPROVADAS. DOLO EVENTUAL. CEGUEIRA DELIBERADA. CONDENAÇÃO

\footnotetext{
96 Sentença Proferida na Ação Penal No 5046512-94.2016.4.04.7000/PR. Página 202. Disponível em: https://abrilveja.files.wordpress.com/2017/07/sentenc3a7a-lula.pdf
} 
MANTIDA. DOSIMETRIA DA PENA. PRESTAÇÃO PECUNIÁRIA. CONDIÇÕES FINANCEIRAS DO RÉU. ANÁLISE DA COMPATIBILIDADE. QUANTUM MANTIDO. CUSTAS PROCESSUAIS. COMPETÊNCIA DO JUÍZO DA EXECUÇÃO. 1. Nos crimes de contrabando e/ou descaminho, a materialidade e a autoria são comprovadas, em regra, com os documentos elaborados e lavrados pela autoridade fiscal competente e responsável pela diligência por ocasião da apreensão das mercadorias. 2. A utilização ou instalação de rádio transceptor instalado sem autorização legal encontra adequação ao tipo penal previsto no art. 70 da Lei $\mathrm{n}^{\circ} 4.117 / 62$. 3. Para a configuração do delito do art. 70 da Lei ${ }^{\circ} 4.117 / 62$, não se exige a comprovação do efetivo uso do radiocomunicador, tampouco que a instalação tenha sido realizada pelo próprio acusado, bastando a prova de que o aparelho estava apto a funcionar. 4. O crime previsto no art. 311 do Código de trânsito Brasileiro tem por finalidade proteger a segurança em locais nos quais, em razão da movimentação ou concentração de pessoas e pelas características da via, o motorista deveria adotar comportamento mais prudente, que se revela na velocidade reduzida e na atenção redobrada, resguardando a incolumidade pública. 5. O crime de receptação encontra previsão no art. 180 do Código Penal; a ocorrência do tipo pressupõe dolo direto sobre a ilicitude do objeto de receptação, revelado, normalmente, pelas circunstâncias do caso concreto. 6. Comprovados a autoria, a materialidade e o dolo, e sendo o fato típico, antijurídico e culpável, considerando a inexistência de causas excludentes de ilicitude e de culpabilidade, resta evidenciada a prática dos delitos do artigo 334-A, caput do Código Penal, combinado com o artigo $3^{\circ}$ do Decreto-lei $n^{\circ} 399 / 1968$; artigo $180, \S \S 1^{\circ}$ e $2^{\circ}$, do Código Penal; artigo 70 da Lei $\mathrm{n}^{\circ}$ 4.117/1962 e artigo 311 do Código de Trânsito Brasileiro 7. Age dolosamente não só o agente que quer o resultado delitivo, mas também quem assume o risco de produzi-lo (art. 18, I, do Código Penal). Ao indivíduo que, como proprietário de veículo de transporte de passageiros, bem assim o motorista de viagens aos países vizinhos, que têm como modo de vida o transporte destes passageiros, não é dado excluir a sua responsabilidade criminal escolhendo permanecer ignorante quanto ao objeto ou objetos da carga, quando teriam condições de aprofundar o seu conhecimento. 8. "A dosimetria da pena é matéria sujeita a certa discricionariedade judicial. O Código Penal não estabelece rígidos esquemas matemáticos ou regras absolutamente objetivas para a fixação da pena" (STF, HC 107.409, $1^{\text {a }}$ Turma, Rel. ${ }^{a}$ Ministra Rosa Weber, DJe 09-5-2012), devendo ser tomados em conta os princípios da necessidade e da eficiência, decompostos nos diferentes elementos previstos no artigo 59 do Código Penal, principalmente na censurabilidade da conduta. 9. Apelação criminal desprovida." ${ }^{97}$ (Grifou-se)

No caso supracitado, o defendido teria lucidamente se colocado em uma situação de ignorância para evitar sua responsabilização criminal, o que

\footnotetext{
97 TRF4, ACR 5005154-31.2016.4.04.7007, OITAVA TURMA, Relator JOÃO PEDRO

GEBRAN NETO, juntado aos autos em 22/03/2018.
} 
configuraria uma hipótese análoga ao dolo eventual e, portanto, passível de condenação a título doloso.

O estudo e a observação dos elementos objetivos dos casos em concreto devem ser eficientes, de modo a corroborar a real intenção do agente em se colocar em uma situação de ignorância, criando barreiras e obstáculos para se manter cego em relação ao delito. Não é suficiente apenas a alta probabilidade da ocorrência do delito, visto que a presença apenas desse elemento pode caracterizar uma situação de culpa não punível nos termos da legislação pátria. 


\section{CONSIDERAÇÕES FINAIS}

Diante de todo o exposto, após a devida construção histórica da teoria da cegueira deliberada, demonstrando sua aplicação, interpretação e críticas pelo Direito Comparado, para então traçar um paralelo com o ordenamento jurídico brasileiro, tem-se que sua aplicação nos nossos tribunais é, para dizer o mínimo, preocupante.

A doutrina, não obstante já encontrar uma certa aceitação em países de Civil Law, fora importada de um sistema legislativo completamente distinto do vigente no Brasil, de modo que sua aplicação deve ser prévia e minuciosamente estudada.

Equiparar a ignorância deliberadamente fabricada, quando existente a alta probabilidade de ocorrência de um delito, à figura do dolo eventual, pode ser compreendida como uma disparidade de armas entre a acusação e a defesa.

Conforme demonstrado, a doutrina é alvo de inúmeras críticas, mesmo nos países onde a mesma fora concebida. Isto porque, a teoria da cegueira deliberada trata-se de uma construção doutrinária e jurisprudencial, não encontrando uma previsão específica na legislação. Dessa forma, sua aplicação e interpretação fica plenamente sujeita à subjetividade dos julgadores.

Tal premissa é alarmante, principalmente no cenário político-criminal que nos encontramos atualmente. Todos aspiram por um Brasil diferente, um país com um menor índice de corrupção e taxa de criminalidade, um país onde as desigualdades são reduzidas e todos os serviços são disponíveis a todos. É comum também a atribuição à corrupção como a maior mazela nacional, de modo que dia após dia, a sociedade discute, opina e discorda quanto ao modo necessário para acabar com tão grave mal.

É notório o anseio da população por uma maior reprimenda criminal, muito em razão dos escandalosos esquemas criminosos que foram deflagrados nos últimos anos. Não se discorda de que o criminoso não deve restar impune de seus atos ilícitos, ainda mais no âmbito da operação Lava- 
Jato, onde muitos dos acusados ocupam cargos legislativos de alta relevância para a sociedade, porém não se afigura razoável relativizar preceitos e garantias constitucionais e infraconstitucionais, apenas para satisfazer um sentimento puramente punitivista.

Isto posto, não se pode conceber uma ressuscitação da velha e proscrita responsabilidade penal objetiva, há muito extirpada do ordenamento jurídico pátrio. Admitir uma condenação criminal pelo delito de lavagem de capitais, que apenas prevê em seu escopo a responsabilização pelo dolo, sem que se demonstre, com clareza e indubitabilidade, a consciência e intenção do agente na persecução do ilícito, é antijurídico e inconstitucional, visto que no Brasil vigora o princípio do in dubio pro reo.

Dessa forma, mesmo que se admita a possibilidade da figura do dolo eventual no delito de lavagem de dinheiro, o que é comum na práxis forense atual, não se pode estender o conceito de dolo para abarcar situações culposas, apenas porque o Estado não consegue provar o elemento subjetivo necessário para a configuração do crime.

Nas palavras e lições de Gustavo Henrique Badaró e Pierpaolo Cruz Bottini, “o desconforto político-criminal com tal conclusão (impunidade) não pode ensejar um alargamento do conceito de cegueira deliberada a ponto de caracterizar tal hipótese, que não preenche os requisitos do instituto em discussão, como crime doloso." 98

É óbvio que em certos casos, quando comprovada a conduta dolosa, e que o agente teria de fato se colocado em uma situação de ignorância deliberada para evitar a responsabilização criminal, a teoria é cabível e até bem-vinda. Não se pode dizer que a aplicação da teoria da cegueira deliberada está indo em sentido diametralmente oposto à evolução mundial, vez que quanto maior é o processo de globalização e de interação entre os países, mais complexos são os processos de lavagem de dinheiro. De modo

\footnotetext{
${ }^{98}$ Badaró, Gustavo Henrique e Cruz Bottini, Pierpaolo. Lavagem de dinheiro: Aspectos penais e processuais penais. 2 ed. - São Paulo: Editora Revista dos Tribunais, 2013. Página 146.
} 
que novas teorias e métodos, na qual se inclui a cegueira deliberada, devem ser elaboradas para evitar a impunidade de agentes criminosos.

O que precisa ser evitado a todo custo é a "constatação" do dolo em situações de flagrante culpa, apenas para conseguir a tão almejada condenação. Caso essa prática se torne rotineira, inúmeras outras garantias e proteções constitucionais restaram violadas e relegadas, de modo que uma condenação criminal se tornará juridicamente mais relevante do que a própria liberdade de um indivíduo e o respeito à sua pessoa humana. 


\section{REFERÊNCIAS BIBLIOGRÁFICAS}

ADORNO BANDEIRA ASSUMPÇÃO, Pedro Antonio. A Teoria da Cegueira Deliberada e a Equiparação ao Dolo Eventual. Rio de Janeiro. EMERJ, 2017

BADARÓ, Gustavo Henrique e CRUZ BOTTINI, Pierpaolo. Lavagem de dinheiro: Aspectos penais e processuais penais. 2 ed. - São Paulo: Editora Revista dos Tribunais, 2013.

BADARÓ, Gustavo Henrique e CRUZ BOTTINI, Pierpaolo. Lavagem de dinheiro: Aspectos penais e processuais penais. 3 ed. - São Paulo: Editora Revista dos Tribunais, 2016

BLANCO CORDERO, Isidoro. EI delito de blanqueo de capitales, 4. Ed.

BORGES DE ALBUQUERQUE MELLO, Sebastian e RIBEIRO HERNANDES, Camila. O Delito De Lavagem De Capitais E A Teoria Da Cegueira Deliberada: Compatibilidade No Direito Penal Brasileiro? CONPEDI Law Review. 2017.

BRAGA, Juliana Toralles dos Santos. Lavagem de dinheiro - Origem histórica, conceito e fases. In: Âmbito Jurídico, Rio Grande, XIII, n. 80, set 2010 .

CAPEZ, Fernando. Curso de Direito Penal: Parte Geral. 3. Ed. Rev. E ampl. - São Paulo, Editora Saraiva. 2001.

CHARLOW, Robin. Wilful Ignorance and Criminal Culpability, 70 Tex. L. Rev. 1351 (1992). 
DANIEL, Alex Robert, "Willful Blindness: The Hazards of an Evolving Standard of Knowledge"

D. RODRIGUEZ, Shawn. Caging Careless Birds: Examining Dangers Posed By the Willful Blindness Doctrine in the War on Terror. Published by Penn Law: Legal Scholarship Repository, 2014.

DE ASSIS TOLEDO, Francisco. Princípios Básicos de Direito Penal, Ed. Saraiva, 1992

Harvard Law Review. Criminal Law - Willful Blindness - Ninth Circuit Holds That Motive Is Not An Element Of Willful Blindness. - United States v. Heredia, 483 F.3d 913 (9th Cir.) (en banc), cert. denied, 76 U.S.L.W. 3303 (U.S. Dec. 11, 2007) (No.07-5762)

MIRABETE, Julio Fabbrini. Manual de Direito Penal. 3. Ed. Rev. E ampl. São Paulo, Editora Atlas. 1987

MORO, Sérgio Fernando. Crime de Lavagem de Dinheiro. São Paulo: Editora Saraiva, 2010.

NUCCI, Guilherme de Souza. Código Penal Comentado / Guilherme de Souza Nucci. - 18 ed. rev., atual. e ampl. - Rio de Janeiro, Editora Forense. 2017

NUCCI, Guilherme de Souza. Leis Penais e Processuais Penais Comentadas. - Guilherme de Souza Nucci - 10 ed. Rev. Atual. E ampl. vol. 2 - Rio de Janeiro: Forense 2017.

P. ROBBINS, Ira. The Ostrich Instruction: Deliberate Ignorance as a Criminal Mens Rea, 81 J. Crim. L. \& Criminology 191 (1990-1991). 
RAGUÉS I VALLÈS, Ramon. La ignorancia deliberada em derecho penal. Barcelona: Atelier, 2007.

REGIS PRADO, Luiz. Direito penal econômico / Luiz Regis Prado. 7. Ed. rev. E atual. - São Paulo: Editora Revista dos Tribunais, 2016

WALSH, Brian. The Supreme Court's Willful Blindness Doctrine Opens the Door to More Wrongful Criminal Convictions. June 30, 2011. 